Published in final edited form as:

J Org Chem. 2019 November 01; 84(21): 14092-14100. doi:10.1021/acs.joc.9b02249.

\title{
Stereocontrolled Synthesis of the Aminocyclopentitol Core of Jogyamycin via an Ichikawa Rearrangement Reaction
}

\author{
Nels C. Gerstner, Jennifer M. Schomaker \\ Department of Chemistry, University of Wisconsin-Madison, 1101 University Avenue, Madison, WI \\ 53706 (USA)
}

\begin{abstract}
Jogyamycin is a member of the aminocyclopentitol class of natural products that exhibits significant antiprotozoal activities against diseases that include African sleeping sickness and malaria. Herein, we report a route to the core of this natural product via an underutilized Ichikawa rearrangement as a key step. This route efficiently forms the cyclopentane ring from simple and easily accessible starting materials, and rapidly installs the $\mathrm{C} 1 / \mathrm{C} 4 / \mathrm{C} 5$ polar functional groups. In addition, this strategy shows excellent potential for the preparation of analogues of jogyamycin to study how structural changes impact the selectivity in binding to the ribosome.
\end{abstract}

\section{Graphical Abstract}
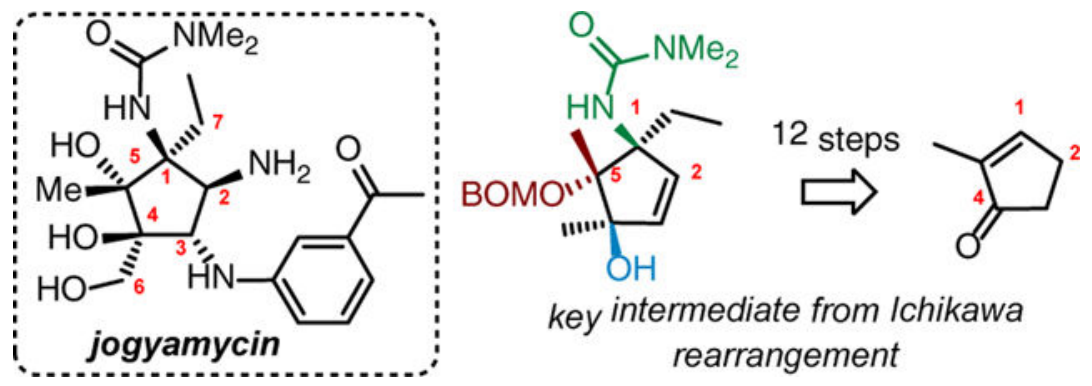

key intermediate from Ichikawa rearrangement

\section{Introduction}

In 2012, Otogura, the Ōmura group reported the structure of a new natural product that was isolated from a strain of Streptomyces bacteria. ${ }^{1}$ This complex aminocyclopentitol was named jogyamycin (1, Figure 1) after the city of Jogjakarta in Indonesia, where the bacteria was first discovered. Jogyamycin displayss significant activity against the protozoa responsible for malaria and African sleeping sickness, while pactamycin $\mathbf{2}$ and analogs 3-5 also show anticancer, antiviral and antimicrobial activities. ${ }^{1,2} \mathrm{X}$-ray crystal structures that show the co-crystallation of $\mathbf{2}$ with the ribosomal 30S subunit indicates that it behaves as a universal inhibitor of translocation in a region of the ribosome that is highly conserved

Corresponding author: schomakerj@chem.wisc.edu.

Supporting Information

The supporting information contains NMR characterization data for all new and old compounds, reaction optimization conditions, unsuccessful substrates, and relevant references. 
between bacterial and mammalian ribosomes, explaining the diverse bioactivities exhibited by these types of aminocyclopentitol natural products. ${ }^{3}$ Intriguingly, minor changes to the core of the aminocyclopentitol ring can significantly alter the activity as compared to the parent compound. ${ }^{2 \mathrm{~d}-\mathrm{h}}$ Continued explorations of structure-activity relationships in this class of compounds are directed towards attenuating cytotoxicity and providing a better understanding of how selectivity between binding to pathogen vs. human ribosomes may be achieved. In this communication, we report an enantioselective synthesis of the core of $\mathbf{1}$ using an Ichikawa rearrangement as a key step. While this strategy ultimately did not deliver 1, the concise and efficient installation of polar functionality at C1/C4/C5 renders this approach convenient for targeting analogues.

In addition to their biological activities, aminocyclopentitols 1-5 are challenging synthetic targets, ${ }^{4}$ as each carbon of the cyclopentane core bears either a stereodefined amine or alcohol. C1-C3 in 1 is comprised of three contiguous carbons with distinct amine functional groups, while $\mathrm{C} 4 / \mathrm{C} 5 / \mathrm{C} 1$ displays three contiguous fully substituted carbons. The stereochemical relationships between these adjacent stereocenters pose their own challenges, including the cis $\mathrm{C} 1$ urea/C2 amine and the trans $\mathrm{C} 4 / \mathrm{C} 5$ tertiary alcohols. Despite many elegant studies directed towards $\mathbf{2}$, most approaches to pactamycin utilize the stereodefined $\mathrm{C} 7$ alcohol as an effective lynchpin early in the synthesis to set the remaining stereocenters through diastereoselective reactions. The lack of this $\mathrm{C} 7$ alcohol in $\mathbf{1}$ requires a different strategy to construct the core, but only two approaches towards $\mathbf{1}$ have been reported (Scheme 1).

\section{Results and discussion}

In 2016, our group reported an approach to the core of 1, where the versatile intermediate 6 contains the required $\mathrm{C} 1 / \mathrm{C} 5$ heteroatoms, a $\mathrm{C} 2$ alcohol, and a flexible $\mathrm{C} 3 / \mathrm{C} 4$ alkene that can be employed for analogue synthesis (Scheme 1A). A key step in our group's strategy for the synthesis of $\mathbf{6}$ involved an oxidative amination of $\mathbf{9}$ to install polar functionality at the three carbons of the allene, which correspond to $\mathrm{C} 1 / \mathrm{C} 2 / \mathrm{C} 5$ of $\mathbf{1}$. Other key steps involved a highly diastereoselective addition of an isopropenyl organometallic reagent to $\mathbf{1 2}$ to set the C5 stereochemistry in $\mathbf{1 3}$ and a ring-closing metathesis of $\mathbf{7}$ to furnish $6 .{ }^{5}$ The only other route to the core of 1 was reported by Trost in 2018 (Scheme 1B). ${ }^{6}$ The $\mathrm{C} 1$ urea was proposed to form through a clever late-stage Hofmann rearrangement of $\mathbf{1 4}$, while the key cyclopentane ring of $\mathbf{1 6}$ arises from a Pd- catalyzed [3+2] cycloaddition of $\mathbf{1 7}$ and 18. In the forward sense, cyclization was achieved with catalytic $[\mathrm{Pd}($ allyl $) \mathrm{Cp}]$ in the presence of a chiral Trost ligand; interestingly, the product (ent)-16 was the opposite enantiomer required for $\mathbf{1}$. Oxidation state manipulations of the $\mathrm{C} 2 / \mathrm{C} 3$ groups to furnish the trans diamine was followed by protection to an oxalamide in (ent)-15. Installation of a $\mathrm{C} 4$ alkene and dihydroxylation delivered 19. The key Hofmann rearrangement of $\mathbf{2 0}$ to 21 was successfully promoted using PhINTs, where the oxalamide prevents competing formation of a cyclic urea. Installation of the $N, N$-dimethylurea of 22 proceeded smoothly; unfortunately, the ketone of $\mathbf{2 2}$ proved resistant towards nucleophilic attack, likely due to steric hindrance posed by the flanking, fully substituted C1/C4 stereocenters. Despite this setback, the Trost 
route rapidly accessed four of the stereocenters on the ring and successfully differentiated the $\mathrm{C} 1-\mathrm{C} 3$ amines.

The challenges inherent in dealing with intermolecular manipulations of polar functionalities in the highly congested cyclopentane ring of $\mathbf{1}$ at a late stage in the synthesis inspired us to consider a new strategy to set the key $\mathrm{C} 1 / \mathrm{C} 2$ amines through the use of sequential Ichikawa ${ }^{7}$ and Overman rearrangements (Scheme 2). We were fully aware of the hurdles that might be encountered employing this approach, particularly in such a compact and densely functionalized environment. However, the benefits of successful implementation, including the use of easily accessible starting materials, potential for enantioselective synthesis, minimal oxidation state manipulations, the opportunity to showcase a lesser known [3,3]sigmatropic rearrangement in a complex molecule, and the ability to rapidly obtain a variety of new analogues of $\mathbf{1}$, outweighed the potential risks.

In the retrosynthetic analysis (Scheme 2), transformation of $\mathbf{2 3}$ to $\mathbf{1}$ relies on chemistry reported by Hanessian in his total synthesis of 2 to install the heteroatoms at $\mathrm{C} 3 / \mathrm{C} 4 .{ }^{4 \mathrm{a}} \mathrm{An}$ Overman rearrangement of $\mathbf{2 4}$ was proposed to concomitantly install the $\mathrm{C} 2$ amine with the correct stereochemistry and position the $\mathrm{C} 3 / \mathrm{C} 4$ alkene in $\mathbf{2 3}$. The rationale for this particular disconnection was strengthened by the potential to form the $\mathrm{C} 2$ amine via an Ichikawa rearrangement, should the Overman fail. Installation of the $\mathrm{C} 1$ urea of $\mathbf{2 4}$ would proceed through an Ichikawa rearrangement of 25. This variation on the more well-known Overman rearrangement is underutilized in the broader synthetic community, but proceeds at significantly lower temperatures and produces a useful isocyanate intermediate that offers product diversity, depending on the subsequent nucleophile selection. In addition, while both sequential Overman and Ichikawa rearrangements have been reported, ${ }^{8}$ to our knowledge, there are no examples of tandem Ichikawa/Overman rearrangements, a transformation that could prove to be a convenient and general solution for differentiating two adjacent nitrogenbearing stereocenters. Finally, the cis $\mathrm{C} 3 / \mathrm{C} 4$ diol in $\mathbf{2 5}$ would be formed in a series of steps from enone 26, accessible in a few steps from 2-methyl-2-cyclopenten-1-one. In the forward route directed towards the preparation of the Ichikawa rearrangement precursor (Scheme 3), enone 27 was subjected to a known enantioselective cuprate addition using $\mathrm{Cu}(\mathrm{OTf})_{2}$ and ligand 28, as reported by Alexakis and co-workers, to give $\mathbf{3 0}$ in $80 \%$ ee. ${ }^{9}$ The easy accessibility of this ligand was the primary reason it was utilized in these studies; if we should use the tandem Ichikawa/Overman strategy for the syntheses of enantioenriched analogues of $\mathbf{1}$, we plan to survey more specialized ligands reported by Alexakis that yield higher ee. ${ }^{9}$ The intermediate magnesium enolate was trapped as the silyl enol ether 29; the crude material was then treated with DMDO in a Rubottom oxidation to give a mixture of diastereomers. While $\mathbf{3 0}$ was confirmed as the major diastereomer ${ }^{10,11}$ through a NOESY analysis of a later intermediate (see the Supplementary Information for further details), the $d r$ was unfortunately low. Nonetheless, the ready accessibility, low cost, and easy separation of the diastereomers rendered this reaction sufficient to assess the viability of this approach to 1 . We did undertake initial attempts to utilize $m$-CPBA or MoOPH as alternative oxidants; however, these reagents resulted in predominant formation of the undesired diastereomer from reaction at the more hindered face of the silyl enol ether. Inoue observed similar stereochemistry in oxidations of silyl enol ethers derived from a cyclopentenones with $m$ - 
CPBA $;{ }^{10}$ calculations indicated torsional strain in the transition state is responsible for the unexpected selectivity.

The desired diastereomer of the a-hydroxy ketone $\mathbf{3 0}$ was then converted to the enone, first by protection of the tertiary alcohol as a BOM ether to furnish $\mathbf{3 1}$, followed by formation of a silyl enol ether and subsequent oxidation with IBX and 4-methoxypyridine oxide to deliver 26. ${ }^{12}$ Any remaining starting material $\mathbf{3 1}$ could be easily separated from $\mathbf{2 6}$ and re-subjected to the reaction conditions to improve the overall yield of the transformation. The BOM group was essential to moving the material forward to the key Ichikawa rearrangement step, as the use of other standard protecting groups resulted in problems with deprotection later in the synthesis.

The next sequence of reactions was designed to install the C-4/C-6 bond in 32 through the addition of $\mathrm{MeMgBr}$ to 26. The absence of $\mathrm{CeCl}_{3}-2 \mathrm{LiCl}^{13}$ resulted in a 3:1 mixture of 1,2and 1,4-addition products, albeit in >20:1 $d r$ for both of the $\mathrm{C} 4$ alcohols. In contrast, while the inclusion of an equimolar amount of $\mathrm{CeCl}_{3}-2 \mathrm{LiCl}$ also resulted in a high $d r$ of the product, the regioselectivity was significantly improved to completely favor the desired 1,2addition product 32. Our previous experience with the isolation of sensitive cyclopentenols in other routes to $\mathbf{1}$, where any adventitious acid gave decomposition of the product, led us to carry out the directed epoxidation immediately on the crude $\mathbf{3 2}$ to give the epoxide $\mathbf{3 3}$ in good isolated yield and a high $d r$ of $>20: 1$; none of the other diastereomer was observed by ${ }^{1} \mathrm{H}$ NMR. The extreme facial bias in the organometallic addition to $\mathbf{2 6}$ is noteworthy, in that it occurs adjacent to a quaternary carbon bearing two groups of similar size. The preference may be due to the C-1 Et group effectively blocking the approach of the organometallic along the Bürgi-Dunitz angle, although chelation between the adjacent ether and the carbonyl may also be operative. Similar diastereoselectivity for the 1,2-addition has been observed in other cyclopentenones. ${ }^{14}$

The preparation of the substrate for the key Ichikawa rearrangement required conversion of the epoxide of $\mathbf{3 3}$ to allylic alcohol 36. The $\mathrm{C} 4$ alcohol was first protected with an orthogonal $-\mathrm{CH}_{2} \mathrm{OPMB}$ group to give 34 , which was followed by a highly regioselective ring-opening with $\mathrm{PhSeNa}$ to afford 35, likely due to less steric congestion at $\mathrm{C} 2$ compared to $\mathrm{C} 3$ in $34 .{ }^{15}$ Finally, 35 was transformed to the allylic alcohol 36 by oxidation of the intermediate selenide with $\mathrm{H}_{2} \mathrm{O}_{2}$.

Treatment of the alcohol $\mathbf{3 6}$ with trichloroacetyl isocyanate (TAI) delivered the carbamate $\mathbf{2 5}$ in excellent yield (Scheme 4). The Ichikawa rearrangement was promoted with a combination of $\mathrm{CBr}_{4} / \mathrm{PPh}_{3} / \mathrm{Et}_{3} \mathrm{~N} ;{ }^{8,16}$ gratifyingly, 25 was smoothly converted to the isocyanate intermediate 37 , which was then trapped with $\mathrm{Me}_{2} \mathrm{NH}$ to efficiently install the $\mathrm{C} 1$ urea in 38. Removal of the $\mathrm{PMBOCH}_{2}$ group with DDQ unmasked the $3^{\circ}$ alcohol in $\mathbf{3 9} ;{ }^{17}$ use of a buffered solution was important for improving the yield of the deprotection. Overall, this sequence proceeds in a sequence from 27 that requires ten purifications by column chromatography, installs all three of the fully substituted stereocenters at C1/C4/C5, and offers opportunities for new analogues via manipulation of the $\mathrm{C} 2 / \mathrm{C} 3$ alkene. 
The next challenge involved implementing the Overmann rearrangement sequence to ideally convert 39 to $\mathbf{4 2}$ after hydrolysis of the resulting trichloroacetimidate (Scheme 5). ${ }^{18}$ Attempts to form the trichloroimidate of $\mathbf{3 9}$ in the presence of various bases unfortunately led to formation of the proposed oxazoline 40. We hypothesize that the $\mathrm{C} 4$ tertiary alcohol does not compete effectively with the urea oxygen for attack on the trichloroacetonitrile, even when the reagent used in large excess; this results in activation of the urea towards nucleophilic attack by the $\mathrm{C} 4$ alcohol to furnish $\mathbf{4 0}$, as determined by NMR of the reaction mixture. Attempts to limit the nucleophilicity of the urea by protecting the -NH via alkylation led only to extensive decomposition.

In light of these issues with the Overman rearrangement, we surmised that a second Ichikawa rearrangement of the $\mathrm{C} 4$ alcohol of $\mathbf{3 9}$ might provide an alternative solution to installing the $\mathrm{C} 2$ amine (Scheme 5, right). While the presence of the free $-\mathrm{NH}$ in the $\mathrm{C} 1$ urea would result in the formation of a second urea between $\mathrm{C} 1$ and $\mathrm{C} 2$, as shown in $\mathbf{4 3}$, success would nonetheless illustrate the feasibility of the second rearrangement event. However, attempts to form the $\mathrm{C} 4$ carbamate from $\mathbf{3 9}$ resulted in the isolation of a trisubstituted alkene that did not contain an additional urea carbonyl. NMR spectroscopy of the crude isolated material supported the formation of $\mathbf{4 1}$, indicating that the oxygen of the urea carbonyl is sufficiently nucleophilic to displace even a relatively poor carbamate leaving group at $\mathrm{C} 4$ via an $\mathrm{S}_{\mathrm{N}} 2^{\prime}$ allylic substitution reaction.

Ultimately, these studies highlighted two major issues in the second rearrangement event, irrespective of whether an Overman or Ichikawa protocol was adopted. The first involved the potential for a $\mathrm{C} 4$ alkoxide to engage with the urea, while the second problem was the propensity of the urea oxygen to displace even poor leaving groups at $\mathrm{C} 4$. To circumvent these complications, the $\mathrm{C} 4$ heteroatom cannot be nucleophilic or easily displaced by the urea oxygen. A possible solution is to exchange the $\mathrm{C} 4$ alcohol for an azide, as this functional group is non-nucleophilic, will not react with the $\mathrm{C} 1$ isocyanate intermediate, and is already primed for the subsequent azide [3,3]-sigmatropic rearrangement. ${ }^{19}$ This potential work-around of a sequential Ichikawa/azide [3.3]-sigmatropic rearrangement is further supported by Hanessian's ability to form the $\mathrm{C} 1$ urea from an isocyanate in the presence of a $\mathrm{C} 2$ azide. ${ }^{4 a}$ Exploration of this alternative route is currently underway in our group and will be reported in due course, should it successfully achieve the total synthesis of jogyamycin.

\section{Conclusions}

In conclusion, we have established a reliable and concise route to a densely functionalized cyclopentene motif 39 which maps onto the core of jogyamycin $\mathbf{1}$. In addition, access to this late stage intermediate may enable facile syntheses of novel analogs of $\mathbf{1}$. Early installation of the $\mathrm{C} 1$ stereocenter in an asymmetric manner enables the challenging $\mathrm{C} 1, \mathrm{C} 4$, and $\mathrm{C} 5$ quaternary stereocenters to be set in a diastereoselective manner. Successful implementation of an Ichikawa rearrangement was complicated by transannular reactions in the densely functionalized core; however, the insight gleaned in these investigations point towards a viable route to finally complete the total synthesis of $\mathbf{1}$. 


\section{Experimental section}

\section{General information.}

All glassware was either oven dried at $130{ }^{\circ} \mathrm{C}$, or flame dried under vacuum and purged with nitrogen before use. All glassware was then allowed to cool in a desiccator filled with Drierite as a desiccant or under nitrogen after placing under vacuum. Unless otherwise specified, reagents were used as obtained from the vendor without further purification. Tetrahydrofuran was passed through an alumina column before use or freshly distilled from a Na/benzophenone ketyl. Diethyl ether was freshly distilled from a Na/benzophenone ketyl. Dichloromethane was freshly distilled from calcium hydride or passed through an alumina column before use. Acetonitrile, toluene and benzene were all freshly distilled from calcium hydride before use. Other solvents were purified using accepted procedures from the sixth edition of "Purification of Laboratory Chemicals". ${ }^{20}$ Air- and moisture-sensitive reactions were performed using standard Schlenk Techniques under nitrogen atmosphere. Analytical thin layer chromatography (TLC) was performed using pre-coated silica gel $60 \mathrm{~F}_{24}$ plates containing a fluorescent indicator. Either $\mathrm{KMnO}_{4}$ or ceric ammonium molybdate (CAM stain) were used to visualize the reaction products. Preparative chromatography for most compounds, unless otherwise specified, was performed using SilicaFlash P60 silica gel (230-400 mesh) via Still's method. ${ }^{21}$ Unless stated otherwise, columns were typically run using a gradient method using EtOAc/hexanes.

${ }^{1} \mathrm{H}$ NMR and ${ }^{13} \mathrm{C}$ NMR spectra were obtained using Bruker Avance III 400 and 500 spectrometers. For ${ }^{1} \mathrm{H}$ NMR, chemical shifts are reported relative to the tetramethylsilane peak $(\delta 0.00 \mathrm{ppm})$, except in some cases when there was no tetramethylsilane peaks in some samples of $\mathrm{C}_{6} \mathrm{D}_{6}$ where the chemical shifts are reported relative to the residual protiated solvent peak (7.16 ppm). ${ }^{13} \mathrm{C}$ NMR spectra were measured at $125 \mathrm{MHz}$ on the same instruments noted above for recording ${ }^{1} \mathrm{H}$ NMR spectra. Chemical shifts are reported relative to the solvent peaks ( $\delta 77.16 \mathrm{ppm}$ for $\mathrm{CDCl}_{3}$ and $128.06 \mathrm{ppm}$ for $\mathrm{C}_{6} \mathrm{D}_{6}$ ). Accurate mass measurements were acquired at the University of Wisconsin, Madison using a Micromass LCT (electrospray ionization or electron impact methods with electrospray ionization - quadrupole - ion trap (orbitrap)). The NMR and Mass Spectrometry facilities are funded by the NSF (CHE-1048642), the University of Wisconsin as well as a generous gift by Paul J. Bender.

\section{Experimental procedures for the synthesis of all compounds.}

(2R,3S)-3-ethyl-2-hydroxy-2-methylcyclopentan-1-one (30).-An oven-dried, 3neck round bottom flask was equipped with a mechanical stirrer, an oven-dried addition funnel, and a septum. ${ }^{9}$ The flask was evacuated and refilled with dry nitrogen three times, then charged with 28 (599.3 mg, $1.17 \mathrm{mmol}, 0.010$ equiv) and $\mathrm{Cu}(\mathrm{OTf})_{2}(329.3 \mathrm{mg}, 0.910$ mmol, 0.0078 equiv). The set-up was again evacuated and refilled with dry nitrogen. The addition funnel was charged with 2-methyl-2-cyclopenten-1-one $27(11.4 \mathrm{~mL}, 116 \mathrm{mmol}$, 1.0 equiv) and $\mathrm{Et}_{2} \mathrm{O}(110 \mathrm{~mL})$, while the flask was charged with additional $\mathrm{Et}_{2} \mathrm{O}(280 \mathrm{~mL})$. The mixture was cooled to $-30^{\circ} \mathrm{C}$ with vigorous stirring using a Cryocool. After the

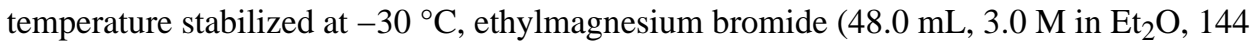
mmol, 1.24 equiv) was added to the mixture; a color change from a dark brown to yellow 
and back to a dark brown was noted within the addition of the first few $\mathrm{mL}$ of the Grignard

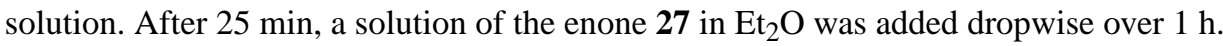
After stirring for $4 \mathrm{~h}$, distilled HMPA (42.0 mL, $241 \mathrm{mmol}, 2.08$ equiv) was added to the reaction and the mixture stirred for $25 \mathrm{~min}$. The addition funnel was then charged with $\mathrm{Et}_{3} \mathrm{~N}$ (34.0 mL, $244 \mathrm{mmol}, 2.10$ equiv) and trimethylchlorosilane (29.5 mL, $232 \mathrm{mmol}, 2.0$ equiv, freshly distilled from $\mathrm{CaH}_{2}$ ) and the mixture added dropwise to the reaction. The mixture was stirred for $2 \mathrm{~h}, 600 \mathrm{~mL}$ of pentanes added, and then the cold slurry poured into $150 \mathrm{~mL}$ of pentanes and $350 \mathrm{~mL}$ of water. The layers were separated, and the aqueous layer extracted with $400 \mathrm{~mL}$ of pentanes. The combined organics were washed with $200 \mathrm{~mL}$ of water, then $200 \mathrm{~mL}$ of brine. The organics were dried over $\mathrm{Na}_{2} \mathrm{SO}_{4}$ and the solvent was removed under reduced pressure. The crude material was stored in a $-78{ }^{\circ} \mathrm{C}$ freezer overnight. A fritted funnel was loaded with $100 \mathrm{~g}$ of silica gel that had been thoroughly wetted with pentanes. The crude material was loaded onto the silica and rapidly filtered through the plug using 1.5 $\mathrm{L}$ of pentanes. The solvent was removed under reduced pressure to yield a slightly peachcolored liquid consisting of the silyl enol ether 29 (14.3 g, $72.1 \mathrm{mmol}, 62 \%$ crude yield).

The second step of the sequence involves oxidation of the silyl enol ether $\mathbf{2 9}$ to the $\mathbf{a}$ hydroxyketone 30. Due to the dilute nature of solutions of DMDO, the oxidation reaction was split between two separate flasks that were later combined for a single purification. A stock solution of $3.86 \mathrm{~g}$ of $\mathrm{NH}_{4} \mathrm{~F}$ in $700 \mathrm{~mL}$ of $\mathrm{MeOH}$ was prepared and set aside. A round bottom flask equipped with a stir bar was cooled to $-78^{\circ} \mathrm{C}$ and charged with the DMDO solution (1.25 L, $0.046 \mathrm{M}$ in acetone, $57.5 \mathrm{mmol}, 1.3$ equiv) and $\mathrm{CH}_{2} \mathrm{Cl}_{2}$ (88 $\mathrm{mL}$ ). A portion of the silyl enol ether 29 ( $8.78 \mathrm{~g}, 44.2 \mathrm{mmol}, 1.0$ equiv) was added slowly once the internal temperature of the solution had reached $-75^{\circ} \mathrm{C}$. After $1.5 \mathrm{~h}$, the $\mathrm{NH}_{4} \mathrm{~F}$ solution $(370 \mathrm{~mL})$ was added and the flask was allowed to warm to room temperature over $11 \mathrm{~h}$. A second round bottom flask equipped with a stir bar was cooled to $-78{ }^{\circ} \mathrm{C}$ and charged with the remainder of the DMDO solution $(625 \mathrm{ml}, 0.059 \mathrm{M}$ in acetone, $36.9 \mathrm{mmol}, 1.3$ equiv) and $\mathrm{CH}_{2} \mathrm{Cl}_{2}(56 \mathrm{~mL})$. Again, once the internal temperature of the solution had reached $-75^{\circ} \mathrm{C}$, the balance of the silyl enol ether 29 (5.53 g, $27.9 \mathrm{mmol}, 1.0$ equiv) was added. After $1.5 \mathrm{~h}$, the $\mathrm{NH}_{4} \mathrm{~F}$ solution $(230 \mathrm{~mL})$ was added and the solution was allowed to warm to room temperature over $11 \mathrm{~h}$. At this point, the two reaction solutions were combined and the solvent was carefully removed under reduced pressure. When $\sim 100 \mathrm{~mL}$ of solution remained, the crude material was diluted with $\mathrm{CH}_{2} \mathrm{Cl}_{2}(600 \mathrm{~mL})$ and water $(400 \mathrm{~mL})$. The layers were separated, and the aqueous layer was extracted two more times with $\mathrm{CH}_{2} \mathrm{Cl}_{2}$ before the combined organics were washed with brine. The organics were dried over $\mathrm{Na}_{2} \mathrm{SO}_{4}$ and the solvent carefully removed under reduced pressure. The crude material was dry loaded with Celite ( $30 \mathrm{~g}$ ) and purified via column chromatography (330 g column, 0 to $100 \% \mathrm{Et}_{2} \mathrm{O} /$ hexanes $)$. The major diastereomer 30 (5.03 g, $35.4 \mathrm{mmol}, 30 \%$ yield) and the minor diastereomer $(3.71 \mathrm{~g}, 26.1 \mathrm{mmol}, 22 \%$ yield) were completely separable as yellow oils. The combined material $(8.74 \mathrm{~g}, 61.4 \mathrm{mmol}, 53 \%$ yield from the enone, $85 \%$ yield from the crude silyl enol ether) was obtained in a 1.36:1 $d r$. Major diastereomer 30: ${ }^{1} \mathrm{H}$ NMR (500 $\left.\mathrm{MHz}, \mathrm{CDCl}_{3}\right) \delta 2.50(\mathrm{~s}, 1 \mathrm{H}), 2.44(\mathrm{ddd}, J=19.5,9.9,1.6 \mathrm{~Hz}, 1 \mathrm{H}), 2.24$ (dt, $J=19.6,9.8$ $\mathrm{Hz}, 1 \mathrm{H}), 2.17-2.10$ (m, 1H), 1.86 (dddd, $J=12.1,8.9,7.0,5.4 \mathrm{~Hz}, 1 \mathrm{H}), 1.70$ (dqd, $J=12.9$, 7.5, $5.3 \mathrm{~Hz}, 1 \mathrm{H}), 1.42-1.30(\mathrm{~m}, 2 \mathrm{H}), 1.08(\mathrm{~s}, 3 \mathrm{H}), 1.02(\mathrm{t}, J=7.4 \mathrm{~Hz}, 3 \mathrm{H}) .{ }^{13} \mathrm{C}\left\{{ }^{1} \mathrm{H}\right\} \mathrm{NMR}$ $\left(126 \mathrm{MHz} \mathrm{CDCl}_{3}\right) \delta 221.3,79.5,48.0,33.4,23.3,22.5,18.0,12.1$. HRMS (ESI) $\mathrm{m} / \mathrm{z}$ 
calculated for $\mathrm{C}_{8} \mathrm{H}_{14} \mathrm{O}_{2}\left[\mathrm{M}+\mathrm{NH}_{4}\right]^{+}$160.1332, found 160.1332. Minor diastereomer (SI-30): ${ }^{1} \mathrm{H}$ NMR $\left(500 \mathrm{MHz}, \mathrm{CDCl}_{3}\right) \delta 2.38(\mathrm{ddd}, J=19.3,8.7,4.7 \mathrm{~Hz}, 1 \mathrm{H}), 2.25$ (ddd, $J=19.3$, 9.3, $7.4 \mathrm{~Hz}, 1 \mathrm{H}), 2.09-1.99(\mathrm{~m}, 1 \mathrm{H}), 1.90(\mathrm{~d}, J=1.7 \mathrm{~Hz}, 1 \mathrm{H}), 1.82-1.75(\mathrm{~m}, 1 \mathrm{H}), 1.75-$ $1.65(\mathrm{~m}, 2 \mathrm{H}), 1.27(\mathrm{~s}, 3 \mathrm{H}), 1.26-1.18(\mathrm{~m}, 1 \mathrm{H}), 0.98(\mathrm{t}, J=7.4 \mathrm{~Hz}, 3 \mathrm{H}) .{ }^{13} \mathrm{C}\left\{{ }^{1} \mathrm{H}\right\} \mathrm{NMR}$ $\left(126 \mathrm{MHz} \mathrm{CDCl}_{3}\right) \delta$ 219.6, 77.7, 48.3, 33.7, 23.2, 22.8, 20.8, 12.2. HRMS (ESI-Q-IT) m/z: $\left[\mathrm{M}+\mathrm{NH}_{4}\right]^{+}$Calcd for $\mathrm{C}_{8} \mathrm{H}_{14} \mathrm{O}_{2}$ 160.1332; Found 160.1331. For confirmation of the stereochemistry of Compound 30, please see the information on Compound 36.

(2R,3S)-2-[(benzyloxy)methoxy]-3-ethyl-2-methylcyclopentan-1-one (31).-A

flame-dried, round bottom flask equipped with a stir bar and a reflux condenser was charged with $i-\operatorname{Pr}_{2} \mathrm{NEt}$ (17.5 mL, $100 \mathrm{mmol}, 5.0$ equiv) and 30 (2.86 g, $20.1 \mathrm{mmol}, 1.0$ equiv) in $\mathrm{CH}_{2} \mathrm{Cl}_{2}$ (100 mL). Benzyl chloromethylether $(8.25 \mathrm{~mL}, 59.8 \mathrm{mmol}, 3.0$ equiv) was added and the solution was refluxed. After confirming complete conversion by NMR after $6 \mathrm{~h}$, the solution was cooled to room temperature and diluted with $\mathrm{Et}_{2} \mathrm{O}$ and saturated $\mathrm{NH}_{4} \mathrm{Cl}$. The aqueous layer was extracted three times with portions of $\mathrm{Et}_{2} \mathrm{O}$. The combined organics were washed with water and brine, followed by drying over $\mathrm{Na}_{2} \mathrm{SO}_{4}$. The solvent was removed under reduced pressure, the crude material dry loaded with Celite (20 g) and purified via column chromatography (330 g column, 0 to $60 \% \mathrm{Et}_{2} \mathrm{O} /$ hexanes). The acetal 31 (4.14 g, $15.8 \mathrm{mmol}, 79 \%$ yield) was isolated as a slightly cloudy liquid. ${ }^{1} \mathrm{H} \mathrm{NMR}\left(500 \mathrm{MHz}, \mathrm{CDCl}_{3}\right)$ $\delta 7.36-7.30(\mathrm{~m}, 4 \mathrm{H}), 7.30-7.26(\mathrm{~m}, 1 \mathrm{H}), 5.00(\mathrm{~d}, J=7.7 \mathrm{~Hz}, 1 \mathrm{H}), 4.77$ (d, J= $7.7 \mathrm{~Hz}$, $1 \mathrm{H}), 4.62\left(\mathrm{ABq}, \Delta \delta_{\mathrm{AB}}=0.02, J_{A B}=11.8 \mathrm{~Hz}, 2 \mathrm{H}\right), 2.38-2.13(\mathrm{~m}, 4 \mathrm{H}), 1.67(\mathrm{dqd}, J=14.8$, 7.4, $4.1 \mathrm{~Hz}, 1 \mathrm{H}), 1.39-1.21(\mathrm{~m}, 2 \mathrm{H}), 1.16(\mathrm{~s}, 3 \mathrm{H}), 0.98(\mathrm{t}, J=7.4 \mathrm{~Hz}, 3 \mathrm{H}) .{ }^{13} \mathrm{C}\left\{{ }^{1} \mathrm{H}\right\} \mathrm{NMR}$ $\left(126 \mathrm{MHz} \mathrm{CDCl}_{3}\right) \delta 219.1,138.0,128.5,128.1,127.8,90.4,84.0,70.2,44.6,35.0,23.2$, 22.2, 16.5, 12.1. HRMS (ESI-Q-IT) m/z: $\left[\mathrm{M}+\mathrm{NH}_{4}\right]^{+}$Calcd for $\mathrm{C}_{16} \mathrm{H}_{22} \mathrm{O}_{3}$ 280.1907; Found 280.1905 .

(4S,5R)-5-[(benzyloxy)methoxy]-4-ethyl-5-methylcyclopent-2-en-1-one (26)-—A flame-dried, round bottom flask equipped with stir bar was taken into the glovebox and charged with 31 (264.7 mg, $1.01 \mathrm{mmol}, 1.0$ equiv). The flask was capped with a septum, removed from the box and charged with THF $(10 \mathrm{~mL})$. The solution was cooled to $-45^{\circ} \mathrm{C}$ and NaHMDS (1.30 mL, $1 \mathrm{M}$ in THF, $1.30 \mathrm{mmol}, 1.3$ equiv) added in a dropwise fashion. After $30 \mathrm{~min}$, chlorotrimethylsilane $(0.20 \mathrm{~mL}, 1.6 \mathrm{mmol}, 1.6$ equiv, freshly distilled from $\mathrm{CaH}_{2}$ ) was added and the reaction stirred for $1 \mathrm{~h}$. The cold mixture was then poured into pentanes $(25 \mathrm{~mL})$ and saturated $\mathrm{NH}_{4} \mathrm{Cl}(12 \mathrm{~mL})$. The phases were quickly separated and the aqueous layer extracted two more times with pentanes $(15 \mathrm{~mL})$. The combined organics were washed with water, then saturated $\mathrm{NH}_{4} \mathrm{Cl}$, dried over $\mathrm{Na}_{2} \mathrm{SO}_{4}$ and the solvent removed under reduced pressure. The crude material was azeotroped with toluene $(2.0 \mathrm{~mL})$ under high vacuum to remove any silanol byproducts. A second flask equipped with a stir bar was charged with IBX (424.5 mg, $1.52 \mathrm{mmol}, 1.5$ equiv) and 4-methoxypyridine $N$-oxide hydrate (218.4 mg, 1.5 equiv). The flask was covered with aluminum foil and the light in the hood was extinguished prior to the addition of DMSO $(3.75 \mathrm{~mL})$. Once the IBX-MPO solution was homogenous, the silyl enol ether was diluted with DMSO $(0.50 \mathrm{~mL})$ and $\mathrm{CH}_{2} \mathrm{Cl}_{2}(0.20 \mathrm{~mL})$. The IBX-MPO solution was then poured into the silyl enol ether solution and the flask covered with aluminum foil. After stirring for $18 \mathrm{~h}$, the solution was diluted with $\mathrm{Et}_{2} \mathrm{O}(25 \mathrm{~mL})$, saturated $\mathrm{NaHCO}_{3}(15 \mathrm{~mL})$, and saturated $\mathrm{Na}_{2} \mathrm{~S}_{2} \mathrm{O}_{3}(15 \mathrm{~mL})$. The layers 
were separated and the aqueous layer further extracted three times with $\mathrm{Et}_{2} \mathrm{O}$. The combined organics were washed once with saturated $\mathrm{NaHCO}_{3}$, twice with water, and one time with brine. The organics were then dried over $\mathrm{Na}_{2} \mathrm{SO}_{4}$ and the solvent removed under reduced pressure. The crude material was dry loaded with Celite and purified via column chromatography (40 g column, 0 to $50 \% \mathrm{Et}_{2} \mathrm{O} /$ hexanes). A portion of the ketone 31 (54.7 $\mathrm{mg}, 0.209 \mathrm{mmol}, 21 \%$ ) was recovered in addition to the desired enone product $\mathbf{2 6}$ (151.9 $\mathrm{mg}, 0.583 \mathrm{mmol}, 58 \%$ yield, $73 \%$ based on recovered starting material). ${ }^{1} \mathrm{H}$ NMR (500 $\left.\mathrm{MHz}, \mathrm{CDCl}_{3}\right) \delta 7.59(\mathrm{dd}, J=6.2,2.2 \mathrm{~Hz}, 1 \mathrm{H}), 7.38-7.25(\mathrm{~m}, 5 \mathrm{H}), 6.18(\mathrm{dd}, J=6.2,2.3$ $\mathrm{Hz}, 1 \mathrm{H}), 4.99(\mathrm{~d}, J=7.6 \mathrm{~Hz}, 1 \mathrm{H}), 4.79(\mathrm{~d}, J=7.6 \mathrm{~Hz}, 1 \mathrm{H}), 4.61\left(\mathrm{ABq}, \Delta \delta_{\mathrm{AB}}=0.03, J_{A B}=\right.$ $11.8 \mathrm{~Hz}, 2 \mathrm{H}), 3.08$ (ddt, $J=10.1,5.8,2.3 \mathrm{~Hz}, 1 \mathrm{H}), 1.84-1.72(\mathrm{~m}, 1 \mathrm{H}), 1.34$ (dtd, $J=13.7$, 7.2, $2.4 \mathrm{~Hz}, 1 \mathrm{H}), 1.29(\mathrm{~s}, 3 \mathrm{H}), 1.08(\mathrm{t}, J=7.4 \mathrm{~Hz}, 3 \mathrm{H}) .{ }^{13} \mathrm{C}\left\{{ }^{1} \mathrm{H}\right\} \mathrm{NMR}\left(126 \mathrm{MHz}, \mathrm{CDCl}_{3}\right) \delta$ 209.2, 164.7, 137.9, 130.7, 128.5, 128.0, 127.8, 90.9, 82.9, 70.1, 51.4, 22.0, 19.3, 12.4. HRMS (ESI-Q-IT) m/z: [M+NH$]^{+}$Calcd for $\mathrm{C}_{16} \mathrm{H}_{20} \mathrm{O}_{3} 278.1751$; Found 278.1747.

\section{(1R,2R,3R,4S,5R)-3-[(benzyloxy)methoxy]-4-ethyl-2,3-dimethyl-6-}

oxabicyclo[3.1.0]hexan-2-ol (33).-A flame-dried, round bottom flask equipped with a stir bar was taken into the glovebox and charged with anhydrous $\mathrm{CeCl}_{3}(2.91 \mathrm{~g}, 11.8 \mathrm{mmol}$, 1.53 equiv ${ }^{13}$ and $\mathrm{LiCl}$ (1.02 g, $24.0 \mathrm{mmol}, 3.10$ equiv). The flask was sealed with a septum, removed from the glovebox and charged with THF $(47 \mathrm{~mL})$. The mixture was stirred at room temperature for $19 \mathrm{~h}$, eventually turning into a homogenous, yellow, opaque solution. A flame-dried conical flask was taken into the glovebox and charged with 26 (2.01 g, 7.73 mmol, 1.0 equiv). The flask was sealed with a septum, removed from the box and charged with THF $(3.0 \mathrm{~mL})$. The solution was transferred via cannula to the $\mathrm{CeCl}_{3}-2 \mathrm{LiCl}$ solution using a rinse of THF $(3.0 \mathrm{~mL})$. After stirring for $1 \mathrm{~h}$, the flask was cooled to $-78^{\circ} \mathrm{C}$ and stirred for an additional $50 \mathrm{~min}$ before dropwise addition of methylmagnesium bromide (7.0 $\mathrm{mL}, 3 \mathrm{M}$ in $\mathrm{Et}_{2} \mathrm{O}, 21 \mathrm{mmol}, 2.7$ equiv). A pH 7 buffer solution (10 mL, 0.1 M phosphate buffer) was added after $5 \mathrm{~h}$ and the reaction warmed to room temperature before pouring it into a mixture of $\mathrm{Et}_{2} \mathrm{O}$ and $\mathrm{pH} 7$ buffer. The aqueous layer was extracted three times with $\mathrm{Et}_{2} \mathrm{O}$. The combined organics were washed with brine, diluted with $\mathrm{CH}_{2} \mathrm{Cl}_{2}$, dried over $\mathrm{Na}_{2} \mathrm{SO}_{4}$, and the solvent was removed under reduced pressure. The crude alcohol 32 was diluted with $\mathrm{CH}_{2} \mathrm{Cl}_{2}(26 \mathrm{~mL})$ and transferred to a flame-dried round bottom flask equipped with a stir bar. The flask was cooled to $0{ }^{\circ} \mathrm{C}$ and charged with $t$-BuOOH $(1.60 \mathrm{~mL}, \sim 5.5 \mathrm{M}$ in decane, $8.80 \mathrm{mmol}, 1.14$ equiv). A separate flask was charged with $\mathrm{VO}(\mathrm{acac})_{2}(83.5 \mathrm{mg}$, $0.315 \mathrm{mmol}, 0.041$ equiv) and $\mathrm{CH}_{2} \mathrm{Cl}_{2}(77 \mathrm{~mL})$. The $\mathrm{VO}(\mathrm{acac})_{2}$ solution was added via cannula transfer to the allylic alcohol to give a red solution, which was gradually warmed to room temperature. After $4.5 \mathrm{~h}$, another batch of $\mathrm{VO}(\mathrm{acac})_{2}(82.5 \mathrm{mg}, 0.311 \mathrm{mmol}, 0.040$ equiv) was added to restore the red color to the solution. After $2.5 \mathrm{~h}$, more $t$-BuOOH $(1.60$ $\mathrm{mL}, \sim 5.5 \mathrm{M}$ in decane, $8.80 \mathrm{mmol}, 1.14$ equiv) and $\mathrm{VO}(\mathrm{acac})_{2}(85.3 \mathrm{mg}, 0.322 \mathrm{mmol}, 0.042$ equiv) were added. After $1.5 \mathrm{~h}$, an additional aliquot of $t$ - $\mathrm{BuOOH}(1.60 \mathrm{ml}, \sim 5.5 \mathrm{M}$ in decane, $8.80 \mathrm{mmol}, 1.14$ equiv) and $\mathrm{VO}(\text { acac })_{2}(80.1 \mathrm{mg}, 0.302 \mathrm{mmol}, 0.039$ equiv) was added, followed by more $\mathrm{VO}(\mathrm{acac})_{2}(83.2 \mathrm{mg}, 0.314 \mathrm{mmol}, 0.041$ equiv) after the mixture was stirred for another $1.5 \mathrm{~h}$. The reaction mixture was quenched with saturated $\mathrm{Na}_{2} \mathrm{~S}_{2} \mathrm{O}_{3}$ and the aqueous layer was extracted three times with $\mathrm{Et}_{2} \mathrm{O}$. The combined organics were washed with water, then brine. $\mathrm{CH}_{2} \mathrm{Cl}_{2}$ was added to the combined organics, which were then dried over $\mathrm{Na}_{2} \mathrm{SO}_{4}$. The solvent was removed under reduced pressure and the crude 
material dry loaded with Celite ( $13 \mathrm{~g})$. The product was purified via column chromatography (120 g column, 0 to $70 \%$ EtOAc/hexanes) to yield the epoxy alcohol 33 (1.76 g, $6.03 \mathrm{mmol}$, $78 \%$ yield) as an oil. Note: Attempts to circumvent the portionwise addition of $\mathrm{VO}(\mathrm{acac})_{2}$ and $t-B u O O H$ by adding an equivalent amount at the beginning of the epoxidation resulted in a stalled reaction that still required additional portions of catalyst and oxidant to be added periodically. We hypothesize this is due to the extremely hindered tertiary alcohol in 32, as the same batch of $\mathrm{VO}(\mathrm{acac})_{2}$ and $\mathrm{t}-\mathrm{BuOOH}$ did not display these issues with less hindered allylic alcohols. ${ }^{1} \mathrm{H}$ NMR $\left(500 \mathrm{MHz}, \mathrm{CDCl}_{3}\right) \delta 7.37-7.27(\mathrm{~m}, 5 \mathrm{H}), 4.93(\mathrm{~d}, J=6.9 \mathrm{~Hz}$, $1 \mathrm{H}), 4.75(\mathrm{~d}, J=6.9 \mathrm{~Hz}, 1 \mathrm{H}), 4.66(\mathrm{~d}, J=11.8 \mathrm{~Hz}, 1 \mathrm{H}), 4.52(\mathrm{~d}, J=11.8 \mathrm{~Hz}, 1 \mathrm{H}), 3.44(\mathrm{dd}$, $J=3.4,1.4 \mathrm{~Hz}, 1 \mathrm{H}), 3.30(\mathrm{~d}, J=3.4 \mathrm{~Hz}, 1 \mathrm{H}), 2.22(\mathrm{~s}, 1 \mathrm{H}), 1.93(\mathrm{ddd}, J=10.4,4.9,1.4 \mathrm{~Hz}$, $1 \mathrm{H}), 1.67-1.58(\mathrm{~m}, 1 \mathrm{H}), 1.57-1.50(\mathrm{~m}, 1 \mathrm{H}), 1.31(\mathrm{~s}, 3 \mathrm{H}), 1.26(\mathrm{~s}, 3 \mathrm{H}), 1.05(\mathrm{t}, J=7.4 \mathrm{~Hz}$, $3 \mathrm{H}) .{ }^{13} \mathrm{C}\left\{{ }^{1} \mathrm{H}\right\} \mathrm{NMR}\left(126 \mathrm{MHz}, \mathrm{CDCl}_{3}\right) \delta 137.9,128.6,127.9,127.9,89.8,84.4,81.6,69.7$, 60.8, 55.2, 50.0, 21.1, 19.7, 17.7, 12.5. HRMS (ESI-Q-IT) m/z: $\left[\mathrm{M}+\mathrm{NH}_{4}\right]^{+}$Calcd for $\mathrm{C}_{17} \mathrm{H}_{24} \mathrm{O}_{4}$ 310.2013; Found 310.2011.

\section{(1R,2R,3R,4S,5R)-3-[(benzyloxy)methoxy]-4-ethyl-2-[(4- methoxyphenyl)methoxy]-2,3-dimethyl-6-oxabicyclo[3.1.0]hexane (34).-A}

round bottom flask equipped with a stir bar and a reflux condenser was charged with $\mathbf{3 3}$ (121.9 mg, $0.417 \mathrm{mmol}, 1.0$ equiv) and $i-\operatorname{Pr}_{2} \mathrm{NEt}(0.36 \mathrm{~mL}, 2.1 \mathrm{mmol}, 5.0$ equiv). A separate round bottom flask equipped with a stir bar was charged with $\mathrm{PMBOCH}_{2} \mathrm{SMe}(249.7 \mathrm{mg}$, $1.26 \mathrm{mmol}, 3.0$ equiv), the vessel subjected to three cycles of evacuation/nitrogen back-fills, and then charged with $\mathrm{CH}_{2} \mathrm{Cl}_{2}(3.10 \mathrm{~mL})$. This flask was cooled to $-78{ }^{\circ} \mathrm{C}$ for 10 min before the addition of $\mathrm{SO}_{2} \mathrm{Cl}_{2}(0.11 \mathrm{ml}, 1.4 \mathrm{mmol}, 3.4$ equiv) dropwise over $2 \mathrm{~min}$. The reaction mixture was stirred for $1 \mathrm{~h}$, then the flask warmed to room temperature and the solvent removed under reduced pressure. Once the solvent had been removed, the crude $\mathrm{PMBOCH}_{2} \mathrm{Cl}$ was subjected to three evacuation/nitrogen back-fill cycles, then diluted with $\mathrm{CH}_{2} \mathrm{Cl}_{2}(2.25 \mathrm{~mL})$. The solution was transferred to the tertiary alcohol via cannula and followed by a $\mathrm{CH}_{2} \mathrm{Cl}_{2}$ rinse $(2.0 \mathrm{~mL})$. The reaction was refluxed for $51 \mathrm{~h}$, then quenched with water. The aqueous layer was extracted three times with $\mathrm{CH}_{2} \mathrm{Cl}_{2}$, the combined organics dried over $\mathrm{Na}_{2} \mathrm{SO}_{4}$, and the solvent removed under reduced pressure. The crude material was dry loaded with Celite $(1 \mathrm{~g})$ and purified via column chromatography ( $40 \mathrm{~g}$ column, 0 to $15 \% \mathrm{Et}_{2} \mathrm{O} /$ toluene). The protected alcohol 34 (149.2 $\mathrm{mg}, 0.337 \mathrm{mmol}, 81 \%$ yield) was isolated as a slightly impure sample. Note: The reaction is lengthy and does take the full time allotted. The use of saturated $\mathrm{NH}_{4} \mathrm{Cl}$ during the workup is not recommended, as this led to rapid ring-opening of the epoxide with chloride to give a byproduct that was challenging to separate. ${ }^{1} \mathrm{H} \mathrm{NMR}\left(500 \mathrm{MHz}, \mathrm{CDCl}_{3}\right) \delta 7.37-7.26(\mathrm{~m}, 7 \mathrm{H}), 6.90-6.86(\mathrm{~m}$, $2 \mathrm{H}), 5.04(\mathrm{~d}, J=7.2 \mathrm{~Hz}, 1 \mathrm{H}), 4.96\left(\mathrm{ABq}, \Delta \delta_{\mathrm{AB}}=0.01, J_{A B}=7.6 \mathrm{~Hz}, 2 \mathrm{H}\right), 4.76-4.70(\mathrm{~m}$, 2H), $4.68(\mathrm{~d}, J=11.2 \mathrm{~Hz}, 1 \mathrm{H}), 4.55(\mathrm{~d}, J=11.2 \mathrm{~Hz}, 1 \mathrm{H}), 4.49(\mathrm{~d}, J=11.8 \mathrm{~Hz}, 1 \mathrm{H}), 3.80(\mathrm{~s}$, $3 \mathrm{H}), 3.55(\mathrm{~d}, J=3.4 \mathrm{~Hz}, 1 \mathrm{H}), 3.42(\mathrm{dd}, J=3.4,1.4 \mathrm{~Hz}, 1 \mathrm{H}), 1.89$ (ddd, $J=10.5,4.7,1.4 \mathrm{~Hz}$, $1 \mathrm{H}), 1.75-1.64(\mathrm{~m}, 1 \mathrm{H}), 1.64-1.56(\mathrm{~m}, 1 \mathrm{H}), 1.37$ (s, 3H), $1.28(\mathrm{~s}, 3 \mathrm{H}), 1.07$ (t, $J=7.4 \mathrm{~Hz}$, $3 \mathrm{H}) .{ }^{13} \mathrm{C}\left\{{ }^{1} \mathrm{H}\right\} \mathrm{NMR}\left(126 \mathrm{MHz}, \mathrm{CDCl}_{3}\right) \delta 159.4,138.3,130.1,129.9,128.5,127.9,127.7$, 114.0, 90.2, 89.9, 86.2, 85.2, 69.6, 69.2, 58.4, 55.4, 54.9, 49.4, 19.6, 19.3, 18.6, 12.6. HRMS (ESI-Q-IT) m/z: [M+NH$]_{4}{ }^{+}$Calcd for $\mathrm{C}_{26} \mathrm{H}_{38} \mathrm{NO}_{6} 460.2694$; Found 460.2691. 
(1S,2R,3R,4R,5S)-3-[(benzyloxy)methoxy]-4-ethyl-2-[(4methoxyphenyl)methoxy]-2,3-dimethyl-5-(phenylselanyl)cyclopentan-1-ol (35).

-A flame-dried round bottom flask equipped with a stir bar was charged with $\mathrm{Ph}_{2} \mathrm{Se}_{2}$ (276.3 mg, $0.885 \mathrm{mmol}, 5.75$ equiv) and $\mathrm{NaH}$ (47.7 mg, $1.19 \mathrm{mmol}, 7.73$ equiv). Three cycles of evacuation/back-filling with argon were carried out before DMSO $(1.80 \mathrm{~mL})$ was added to the flask and the reaction heated to $50{ }^{\circ} \mathrm{C}$. A separate flame-dried flask equipped with a stir bar was taken into the glovebox and charged with 34 (68.3 mg, 0.154 mmol, 1.0 equiv). The flask was sealed with a septum and evacuated/back-filled with argon. After $1 \mathrm{~h}$, the solution of $\mathrm{PhSeNa}$ was cooled to room temperature and $1.0 \mathrm{~mL}$ added to the flask containing 34. The resulting solution was heated to $100{ }^{\circ} \mathrm{C}$ for $17 \mathrm{~h}$ before the mixture was cooled to room temperature and quenched with brine. The aqueous layer was extracted three times with EtOAc, the combined organics washed one additional time with brine, and dried over $\mathrm{Na}_{2} \mathrm{SO}_{4}$. The solvent was removed under reduced pressure and the crude material dry loaded with Celite $(1 \mathrm{~g})$. The crude material was purified via column chromatography (40 $\mathrm{g}$ column, 0 to $60 \% \mathrm{Et}_{2} \mathrm{O} /$ hexanes) to yield the selenoether 35 (53.5 mg, $0.0892 \mathrm{mmol}, 58 \%$ yield) as an oil. ${ }^{1} \mathrm{H}$ NMR $\left(500 \mathrm{MHz}, \mathrm{CDCl}_{3}\right) \delta 7.64-7.59(\mathrm{~m}, 2 \mathrm{H}), 7.37-7.26(\mathrm{~m}, 5 \mathrm{H})$, $7.24-7.17(\mathrm{~m}, 5 \mathrm{H}), 6.88-6.84(\mathrm{~m}, 2 \mathrm{H}), 4.93(\mathrm{~d}, J=7.3 \mathrm{~Hz}, 1 \mathrm{H}), 4.75(\mathrm{~d}, J=7.3 \mathrm{~Hz}, 1 \mathrm{H})$, $4.64(\mathrm{~d}, J=7.6 \mathrm{~Hz}, 1 \mathrm{H}), 4.62(\mathrm{~d}, J=11.8 \mathrm{~Hz}, 1 \mathrm{H}),), 4.53\left(\mathrm{ABq}, \Delta \delta_{\mathrm{AB}}=0.04, J_{A B}=11.8\right.$ $\mathrm{Hz}, 2 \mathrm{H}), 4.49$ (d, $J=7.4 \mathrm{~Hz}, 1 \mathrm{H}), 4.46$ (d, $J=11.4 \mathrm{~Hz}, 1 \mathrm{H}), 4.05$ (dd, $J=8.3,7.4 \mathrm{~Hz}, 1 \mathrm{H})$, 3.80 (s, 3H), 3.62 (d, $J=8.4 \mathrm{~Hz}, 1 \mathrm{H}), 2.94$ (t, $J=7.4 \mathrm{~Hz}, 1 \mathrm{H}), 1.88$ (ddd, $J=8.9,7.3,5.9$ $\mathrm{Hz}, 1 \mathrm{H}), 1.66$ (ddd, $J=13.6,7.5,6.0 \mathrm{~Hz}, 1 \mathrm{H}), 1.54$ (ddt, $J=13.5,8.9,7.4 \mathrm{~Hz}, 1 \mathrm{H}), 1.28$ (s, $3 \mathrm{H}), 1.28(\mathrm{~s}, 3 \mathrm{H}), 1.06(\mathrm{t}, J=7.5 \mathrm{~Hz}, 3 \mathrm{H}) .{ }^{13} \mathrm{C}\left\{{ }^{1} \mathrm{H}\right\} \mathrm{NMR}\left(126 \mathrm{MHz}, \mathrm{CDCl}_{3}\right) \delta 159.6$, $138.1,135.5,129.7,129.5,129.0,128.5,128.0,127.7,127.7,114.1,89.4,89.0,88.6,87.1$, 82.2, 70.3, 69.7, 55.4, 52.6, 52.0, 25.8, 14.9, 14.7, 13.6. HRMS (ESI-Q-IT) m/z: [M+H] ${ }^{+}$ Calcd for $\mathrm{C}_{32} \mathrm{H}_{40} \mathrm{O}_{6} \mathrm{Se} 601.2063$; Found 601.2059.

(1R,4R,5R)-4-[(benzyloxy)methoxy]-3-ethyl-5-[(4-methoxyphenyl)methoxy]-4,5dimethyl-cyclopent-2-en-1-ol (36).—A 20 dram vial containing 35 (53.5 mg, 0.0892 mmol, 1.0 equiv) was charged with THF $(0.90 \mathrm{~mL})$ and pyridine $(0.015 \mathrm{~mL}, 0.19 \mathrm{mmol}, 2.1$ equiv). The mixture was stirred at room temperature before adding $30 \% \mathrm{H}_{2} \mathrm{O}_{2}(0.028 \mathrm{ml}$, $0.27 \mathrm{mmol}, 3.0$ equiv.). After $18 \mathrm{~h}$, the reaction was diluted with EtOAc and quenched with a 1:1 mixture of saturated $\mathrm{NaS}_{2} \mathrm{O}_{3}$ and $\mathrm{NaHCO}_{3}$. The aqueous layer was extracted three times with EtOAc, the combined organics washed with brine, and dried over $\mathrm{Na}_{2} \mathrm{SO}_{4}$. The material was purified via column chromatography (12 g column, 0 to $50 \%$ EtOAc/hexanes) to furnish the allylic alcohol $36(30.7 \mathrm{mg}, 0.0694 \mathrm{mmol}, 78 \%$ yield $)$ as an oil. ${ }^{1} \mathrm{H} \mathrm{NMR}(500 \mathrm{MHz}$, $\left.\mathrm{CDCl}_{3}\right) \delta 7.37-7.32(\mathrm{~m}, 4 \mathrm{H}), 7.31-7.24(\mathrm{~m}, 3 \mathrm{H}), 6.88(\mathrm{~d}, J=8.6 \mathrm{~Hz}, 2 \mathrm{H}), 5.56(\mathrm{q}, J=2.2$ $\mathrm{Hz}, 1 \mathrm{H}), 5.02(\mathrm{~d}, J=7.0 \mathrm{~Hz}, 1 \mathrm{H}), 4.98(\mathrm{~d}, J=6.8 \mathrm{~Hz}, 1 \mathrm{H}), 4.85$ (d, J=6.9 Hz, 1H), 4.78 (d, $J=7.1 \mathrm{~Hz}, 1 \mathrm{H}), 4.73(\mathrm{~d}, J=11.8 \mathrm{~Hz}, 1 \mathrm{H}), 4.68(\mathrm{~d}, J=11.3 \mathrm{~Hz}, 1 \mathrm{H}), 4.55(\mathrm{~d}, J=11.7 \mathrm{~Hz}$, $1 \mathrm{H}), 4.51(\mathrm{~d}, J=11.2 \mathrm{~Hz}, 1 \mathrm{H}), 4.28-4.24(\mathrm{~m}, 1 \mathrm{H}), 3.80(\mathrm{~s}, 3 \mathrm{H}), 2.23-2.13(\mathrm{~m}, 1 \mathrm{H}), 2.13-$ $2.04(\mathrm{~m}, 1 \mathrm{H}), 1.56(\mathrm{~s}, 3 \mathrm{H}), 1.27(\mathrm{~s}, 3 \mathrm{H}), 1.10(\mathrm{t}, J=7.3 \mathrm{~Hz}, 3 \mathrm{H}) .{ }^{13} \mathrm{C}\left\{{ }^{1} \mathrm{H}\right\} \mathrm{NMR}(126 \mathrm{MHz}$, $\left.\mathrm{CDCl}_{3}\right) \delta 159.6,154.9,138.2,129.8,129.2,128.5,128.0,127.7,123.6,114.1,90.2,90.1$, 89.8, 88.4, 78.6, 70.0, 69.5, 55.4, 20.8, 20.0, 18.7, 11.4. HRMS (ESI-Q-IT) m/z: $\left[\mathrm{M}+\mathrm{NH}_{4}\right]^{+}$ Calcd for $\mathrm{C}_{26} \mathrm{H}_{34} \mathrm{O}_{6} 460.2694$; Found 460.2690. 
The overall stereochemistry of $\mathbf{3 6}$ was confirmed using a NOESY analysis; see the Supplementary Information for details. This analysis also confirms the stereochemical assignment of 30, even though the $\mathrm{C} 1$ stereocenter bearing the ethyl group has been ablated. This is due to two reasons: a) the vanadium-catalyzed, directed epoxidations of allylic alcohols in cyclopentenol scaffolds give exclusively cis epoxy alcohols, and b) the selenoxide elimination occurs through syn elimination. The proton adjacent to the selenoxide intermediate formed from $\mathbf{3 5}$ has too high of a $\mathrm{pKa}$ to be epimerized under the reaction conditions employed, meaning that the epoxide and the ethyl group are on the same face in 34. Since the data above indicates that the allylic alcohol and the C5 methyl are on the same face, this supports our conclusion that the C5 methyl and the ethyl group were also positioned on the same face; thus, the stereochemistry indicated for $\mathbf{3 0}$ has been correctly assigned.

(1R,4R,5R)-4-[(benzyloxy)methoxy]-3-ethyl-5-[(4-methoxyphenyl)methoxy]-4,5dimethyl-cyclopent-2-en-1-yl carbamate (25).-A 20 dram vial containing the allylic alcohol 36 (367.1 mg, $0.830 \mathrm{mmol}, 1.0$ equiv) and equipped with a stir bar was charged with $\mathrm{CH}_{2} \mathrm{Cl}_{2}(4.5 \mathrm{~mL})$ and cooled to $0{ }^{\circ} \mathrm{C}$. Trichloroacetyl isocyanate $(0.12 \mathrm{~mL}, 0.996 \mathrm{mmol}$, 1.20 equiv) was added and the reaction stirred for $1 \mathrm{~h}$. When complete consumption of 36 was indicated by TLC, the solvent was removed under reduced pressure. Once dry, the dram vial was charged with $\mathrm{K}_{2} \mathrm{CO}_{3}$ (69.0 mg, $0.499 \mathrm{mmol}, 0.60$ equiv) and $\mathrm{MeOH}(2.10 \mathrm{~mL})$. The reaction was judged complete by TLC after stirring for $5 \mathrm{~h}$ at room temperature. The solvent was removed under reduced pressure and the crude mixture dissolved in $\mathrm{Et}_{2} \mathrm{O}$ and water.

The aqueous layer was extracted three times with $\mathrm{Et}_{2} \mathrm{O}$, the combined organics washed with brine, and dried over $\mathrm{Na}_{2} \mathrm{SO}_{4}$ before removing the solvent in vacuo. The crude material was dry loaded onto Celite before purifying via column chromatography ( $24 \mathrm{~g}$ column, 0 to $70 \%$ EtOAc/hexanes) to deliver the allylic carbamate 25 (361.4 mg, $0.744 \mathrm{mmol}, 90 \%$ yield $).{ }^{1} \mathrm{H}$ NMR (500 MHz, $\left.\mathrm{CDCl}_{3}\right) \delta 7.38-7.27(\mathrm{~m}, 5 \mathrm{H}), 7.25(\mathrm{~d}, J=8.5 \mathrm{~Hz}, 2 \mathrm{H}), 6.86(\mathrm{~d}, J=8.6$ $\mathrm{Hz}, 2 \mathrm{H}), 5.54(\mathrm{dd}, J=3.1,1.8 \mathrm{~Hz}, 1 \mathrm{H}), 5.25(\mathrm{dt}, J=2.7,1.1 \mathrm{~Hz}, 1 \mathrm{H}), 5.10(\mathrm{~d}, J=7.1 \mathrm{~Hz}$, $1 \mathrm{H}), 4.91(\mathrm{~d}, J=7.3 \mathrm{~Hz}, 1 \mathrm{H}), 4.81(\mathrm{~d}, J=7.1 \mathrm{~Hz}, 1 \mathrm{H}), 4.79(\mathrm{~d}, J=7.3 \mathrm{~Hz}, 1 \mathrm{H}), 4.76(\mathrm{~d}, J=$ $11.8 \mathrm{~Hz}, 1 \mathrm{H}), 4.65$ (d, $J=11.4 \mathrm{~Hz}, 1 \mathrm{H}), 4.55$ (appt d, $J=11.7 \mathrm{~Hz}, 3 \mathrm{H}), 4.49$ (d, $J=11.4 \mathrm{~Hz}$, $1 \mathrm{H}), 3.79$ (s, 3H), $2.27-2.16(\mathrm{~m}, 1 \mathrm{H}), 2.16-2.06(\mathrm{~m}, 1 \mathrm{H}), 1.54(\mathrm{~s}, 3 \mathrm{H}), 1.39$ (s, 3H), 1.10 $(\mathrm{t}, J=7.3 \mathrm{~Hz}, 3 \mathrm{H}) .{ }^{13} \mathrm{C}\left\{{ }^{1} \mathrm{H}\right\} \mathrm{NMR}\left(126 \mathrm{MHz}, \mathrm{CDCl}_{3}\right) \delta 159.3,158.3,156.5,138.2,130.2$, 129.5, 128.6, 128.0, 127.8, 119.9, 114.0, 90.5, 90.3, 90.0, 86.0, 80.3, 69.6, 69.58, 55.4, 20.7, 20.2, 20.1, 11.3. HRMS (ESI-Q-IT) m/z: $\left[\mathrm{M}+\mathrm{NH}_{4}\right]^{+}$Calcd for $\mathrm{C}_{27} \mathrm{H}_{35} \mathrm{NO}_{7}$ 503.2752; Found 503.2744 .

\section{1-[(1S,4R,5R)-5-[(benzyloxy)methoxy]-1-ethyl-4-[(4-methoxyphenyl)methoxy]- 4,5-di-methylcyclopent-2-en-1-yl]-3,3-dimethylurea (38).-A flame-dried round} bottom flask equipped with a stir bar was charged with $\mathrm{PPh}_{3}(488.0 \mathrm{mg}, 1.86 \mathrm{mmol}, 2.50$ equiv) and 25 (361.4 mg, $0.744 \mathrm{mmol}, 1.0$ equiv) in $\mathrm{CH}_{2} \mathrm{Cl}_{2}(10 \mathrm{~mL})$. The flask was cooled to $0{ }^{\circ} \mathrm{C}$ before the addition of $\mathrm{Et}_{3} \mathrm{~N}\left(0.62 \mathrm{~mL}, 4.5 \mathrm{mmol}, 5.8\right.$ equiv). After $15 \mathrm{~min}, \mathrm{CBr}_{4}$ (691.4 mg, $2.08 \mathrm{mmol}, 2.80$ equiv) in $\mathrm{CH}_{2} \mathrm{Cl}_{2}(5.0 \mathrm{~mL})$ was added in a dropwise fashion. The reaction was warmed to room temperature after $1 \mathrm{~h}$ and stirred for an additional $30 \mathrm{~min}$. An aliquot of $\mathrm{Me}_{2} \mathrm{NH}$ (3.35 mL, $2 \mathrm{M}$ in THF, $6.70 \mathrm{mmol}, 9.0$ equiv) was added to the flask, the reaction stirred for $18 \mathrm{~h}$, then quenched with saturated $\mathrm{NH}_{4} \mathrm{Cl}$. The resulting aqueous 
layer was extracted three times with $\mathrm{Et}_{2} \mathrm{O}$, the combined organics washed with brine, dried over $\mathrm{Na}_{2} \mathrm{SO}_{4}$ and the solvent removed under reduced pressure. The crude material was dry loaded with silica ( $2.5 \mathrm{~g}$ ) and purified via column chromatography ( $40 \mathrm{~g}$ column, 0 to $100 \%$ EtOAc/hexanes) to give 38 (189.1 mg, $0.369 \mathrm{mmol}, 50 \%$ yield). ${ }^{1} \mathrm{H}$ NMR (500 MHz, $\left.\mathrm{CDCl}_{3}\right) \delta 7.38-7.31(\mathrm{~m}, 4 \mathrm{H}), 7.31-7.27(\mathrm{~m}, 1 \mathrm{H}), 7.25(\mathrm{~d}, J=8.7 \mathrm{~Hz}, 2 \mathrm{H}), 6.87(\mathrm{~d}, J=8.7$ $\mathrm{Hz}, 2 \mathrm{H}), 6.27(\mathrm{~d}, J=6.4 \mathrm{~Hz}, 1 \mathrm{H}), 5.93(\mathrm{~d}, J=6.4 \mathrm{~Hz}, 1 \mathrm{H}), 5.03(\mathrm{~d}, J=7.1 \mathrm{~Hz}, 1 \mathrm{H}), 4.98(\mathrm{~d}$, $J=7.2 \mathrm{~Hz}, 1 \mathrm{H}), 4.84(\mathrm{~d}, J=7.3 \mathrm{~Hz}, 1 \mathrm{H}), 4.77(\mathrm{~d}, J=7.3 \mathrm{~Hz}, 1 \mathrm{H}), 4.72(\mathrm{~d}, J=11.5 \mathrm{~Hz}, 1 \mathrm{H})$, $4.63(\mathrm{~d}, J=11.6 \mathrm{~Hz}, 1 \mathrm{H}), 4.59(\mathrm{~d}, J=11.4 \mathrm{~Hz}, 1 \mathrm{H}), 4.48(\mathrm{~d}, J=11.4 \mathrm{~Hz}, 1 \mathrm{H}), 4.39$ (s, 1H), 3.80 (s, 3H), 2.77 (s, 6H), $2.11(\mathrm{dq}, J=14.8,7.5 \mathrm{~Hz}, 1 \mathrm{H}), 1.71(\mathrm{dq}, J=14.6,7.3 \mathrm{~Hz}, 1 \mathrm{H})$, $1.42(\mathrm{~s}, 3 \mathrm{H}), 1.40(\mathrm{~s}, 3 \mathrm{H}), 0.93(\mathrm{t}, J=7.4 \mathrm{~Hz}, 3 \mathrm{H}) .{ }^{13} \mathrm{C}\left\{{ }^{1} \mathrm{H}\right\}$ NMR $\left(126 \mathrm{MHz} \mathrm{CDCl}_{3}\right) \delta$ 159.3, 158.0, 138.2, 137.4, 131.6, 130.3, 129.6, 128.6, 128.1, 127.9, 113.9, 92.8, 90.7, 90.1, 90.09, 71.9, 70.3, 68.9, 55.4, 36.4, 28.7, 23.1, 16.1, 9.3. HRMS (ESI-Q-IT) m/z: [M+Na ${ }^{+}$ Calcd $\mathrm{C}_{29} \mathrm{H}_{40} \mathrm{~N}_{2} \mathrm{O}_{6}$ 535.2779; Found 535.2779.

\section{1-[(1S,4R,5R)-5-[(benzyloxy)methoxy]-1-ethyl-4-hydroxy-4,5-} dimethylcyclopent-2-en-1-yl]-3,3-dimethylurea (39).-A round bottom flask equipped with a stir bar was charged with 38 (20.0 mg, $0.0390 \mathrm{mmol}, 1.0$ equiv), $\mathrm{CH}_{2} \mathrm{Cl}_{2}$ $(0.56 \mathrm{~mL}), t-\mathrm{BuOH}(0.06 \mathrm{~mL})$ and a $\mathrm{pH} 7$ buffer $(0.06 \mathrm{~mL}, 0.2 \mathrm{M}$ sodium phosphate buffer $)$. DDQ (14.0 mg, $0.0617 \mathrm{mmol}, 1.6$ equiv) was added with vigorous stirring. An NMR aliquot after $3 \mathrm{~h}$ showed complete conversion of the starting material. The reaction was diluted with $\mathrm{Et}_{2} \mathrm{O}$ and filtered through Celite. The filtrate was washed with $5 \mathrm{~mL}$ of saturated $\mathrm{NaHCO}_{3}$ and $10 \mathrm{~mL}$ of brine. The aqueous layer was extracted three times with $\mathrm{Et}_{2} \mathrm{O}$, the combined organics dried over $\mathrm{Na}_{2} \mathrm{SO}_{4}$ and the solvent removed under reduced pressure. The crude material was purified via column chromatography (0 to $40 \%$ EtOAc/hexanes in $20 \%$ increments, then 40 to $100 \%$ EtOAc/hexanes in $10 \%$ increments) to furnish $39(9.0 \mathrm{mg}$, $0.025 \mathrm{mmol}, 64 \%$ yield) as a thin film. ${ }^{1} \mathrm{H}$ NMR $\left(500 \mathrm{MHz}, \mathrm{CDCl}_{3}\right) \delta 7.37-7.27(\mathrm{~m}, 5 \mathrm{H})$, $5.90(\mathrm{~d}, J=6.1 \mathrm{~Hz}, 1 \mathrm{H}), 5.80(\mathrm{~d}, J=6.1 \mathrm{~Hz}, 1 \mathrm{H}), 4.99$ (d, $J=7.4 \mathrm{~Hz}, 1 \mathrm{H}), 4.89$ (d, $J=7.3$ $\mathrm{Hz}, 1 \mathrm{H}), 4.69-4.58(\mathrm{~m}, 3 \mathrm{H}), 4.34(\mathrm{~s}, 1 \mathrm{H}), 2.85$ (s, 6H), $1.87-1.75$ (m, 2H), 1.38 (s, 3H), $1.34(\mathrm{~s}, 3 \mathrm{H}), 1.01(\mathrm{t}, J=7.5 \mathrm{~Hz}, 3 \mathrm{H}) .{ }^{13} \mathrm{C}\left\{{ }^{1} \mathrm{H}\right\} \mathrm{NMR}\left(126 \mathrm{MHz}, \mathrm{CDCl}_{3}\right) \delta 158.1,138.1$, 137.1, 133.0, 128.6, 127.9, 127.8, 91.5, 90.8, 84.6, 77.2, 72.7, 70.4, 36.4, 29.3, 22.6, 14.5, 9.3. HRMS (ESI-Q-IT) m/z: [M+H] ${ }^{+}$Calcd for $\mathrm{C}_{20} \mathrm{H}_{30} \mathrm{~N}_{2} \mathrm{O}_{4} 363.2278$; Found 363.2274.

(3aS,4S,6aS)-4-[(benzyloxy)methoxy]-3a-ethyl-N,N,4,5-tetramethyl-3aH,4H, 6aH-cyclo-penta[d][1,3]oxazol-2-amine (41).-A 20 dram vial containing 39 (23.5 $\mathrm{mg}, 0.065 \mathrm{mmol}, 1.0$ equiv) and equipped with a stir bar was charged with $\mathrm{CH}_{2} \mathrm{Cl}_{2}(0.32$ $\mathrm{mL})$ and cooled to $0{ }^{\circ} \mathrm{C}$. Trichloroacetyl isocyanate $(9.3 \mu \mathrm{L}, 0.078 \mathrm{mmol}, 1.20$ equiv) was added and the reaction stirred for $2.5 \mathrm{~h}$. When complete consumption of $\mathbf{3 9}$ was indicated by TLC, the solvent was removed under nitrogen. Once dry, the dram vial was charged with $\mathrm{K}_{2} \mathrm{CO}_{3}$ (5.4 mg, $0.039 \mathrm{mmol}, 0.60$ equiv) and $\mathrm{MeOH}(0.16 \mathrm{~mL})$. The reaction was judged complete by TLC after stirring for $5 \mathrm{~h}$ at room temperature. The solvent was removed under reduced pressure and the crude mixture dissolved in $\mathrm{Et}_{2} \mathrm{O}$ and water. The aqueous layer was extracted three times with $\mathrm{Et}_{2} \mathrm{O}$, the combined organics washed with brine, and dried over $\mathrm{Na}_{2} \mathrm{SO}_{4}$ before removing the solvent in vacuo. The crude material was analyzed by ${ }^{1} \mathrm{H}$ NMR $\left(500 \mathrm{MHz}, \mathrm{CDCl}_{3}\right) \delta 7.32-7.27(\mathrm{~m}, 5 \mathrm{H}), 5.60$ (app pent, $\left.J=1.6 \mathrm{~Hz}, 1 \mathrm{H}\right), 5.12(\mathrm{~d}, J=2.5$ $\mathrm{Hz}, 1 \mathrm{H}), 4.69$ (d, $J=7.4 \mathrm{~Hz}, 1 \mathrm{H}), 4.61(\mathrm{~d}, J=11.8 \mathrm{~Hz}, 1 \mathrm{H}), 4.53$ (d, $J=7.4 \mathrm{~Hz}, 1 \mathrm{H}), 4.52$ 
(d, $J=11.8 \mathrm{~Hz}, 1 \mathrm{H}), 2.9(\mathrm{~s}, 6 \mathrm{H}), 1.76(\mathrm{t}, J=1.6 \mathrm{~Hz}, 3 \mathrm{H}), 1.62\left(\mathrm{qd}, \mathrm{ABX}_{3} J=7.3,1.8 \mathrm{~Hz}\right.$, $2 \mathrm{H}), 1.41(\mathrm{~s}, 3 \mathrm{H}), 0.85(\mathrm{t}, J=7.4 \mathrm{~Hz}, 3 \mathrm{H}) .{ }^{13} \mathrm{C}\left\{{ }^{1} \mathrm{H}\right\} \mathrm{NMR}\left(126 \mathrm{MHz}, \mathrm{CDCl}_{3}\right) \delta 166.2$, $161.1,149.7,139.3,129.4,128.9,128.1,93.3,91.0,90.2,83.3,70.5,37.8,26.6,20.8,13.5$, 8.7.

\section{Supplementary Material}

Refer to Web version on PubMed Central for supplementary material.

\section{Acknowledgements}

JMS thanks the NIH 1R01GM111412 and NCG thanks the NIH F31GM122300-02 for funding of this work. We thank Dr. Charles Fry and Dr. Heike Hofstetter, both of the University of Wisconsin-Madison, for assistance with NMR studies. The NMR facilities at UW-Madison are funded by the NSF (CHE-9208463, CHE-9629688) and NIH (RR08389-01).

\section{References and Notes}

(1). Iwatsuki M; Nishihara-Tsukashima A; Ishiyama A; Namatame M; Watanabe Y; Handasah S; Pranamuda H; Marwoto B; Matsumoto A; Takahashi Y; Otoguro K; Ōmura S Jogyamycin, a new antiprotozoal aminocyclopentitol antibiotic, produced by Streptomyces sp. a-WM-JG-16.2. J. Antibiot 2012, 65, 169. [PubMed: 22234298]

(2). (a)White FR Pactamycin. Cancer Chemotherapy Reports 1962, 24, 75. [PubMed: 14000310] (b)Ito T; Roongsawang N; Shirasaka N; Lu W; Flatt PM; Kasanah N; Miranda C; Mahmud T Deciphering pactamycin biosynthesis and engineered production of new pactamycin analogues. ChemBioChem 2009, 10, 2253. [PubMed: 19670201] (c)Lu W; Roongsawang N; Mahmud T Biosynthetic studies and genetic engineering of pactamycin analogs with improved selectivity toward malarial parasites. Chem. Biol 2011, 18, 425. [PubMed: 21513878] (d)Otoguro K; Iwatsuki M; Ishiyama A; Namatame M; Nishihara-Tukashima A; Shibahara S; Kondo S; Yamada H; Ōmura S Promising lead compounds for novel antiprotozoals. J. Antibiot 2010, 63, 381. [PubMed: 20661239] (e)Hanessian S; Vakiti RR; Chattopadhyay AK; Dorich S; Lavallée C Probing functional diversity in pactamycin toward antibiotic, antitumor, and antiprotozoal activity. Bioorg. Med. Chem 2013, 21, 1775. [PubMed: 23434136] (f)Sharpe RJ; Malinowski JT; Sorana F; Luft JC; Bowerman CJ; DeSimone JM; Johnson JS Preparation and Biological Evaluation of Synthetic and Polymer-Encapsulated Congeners of the Antitumor Agent Pactamycin: Insight into Functional Group Effects and Biological Activity. Bioorg. Med. Chem 2015, 23, 1849. [PubMed: 25792144] (g)Almabruk KH; Lu W; Li X; Abugreen M; Kelly JX; Mahmud T Mutasynthesis of fluorinated pactamycin analogues and their antimalarial activity. Org. Lett 2013, 15, 1678. [PubMed: 23521145] (h)Brumsted CJ; Carpenter EL; Indra AK; Mahmud T Asymmetric synthesis and biological activities of pactamycin-inspired aminocyclopentitols. Org. Lett 2018, 20, 397. [PubMed: 29319326]

(3). (a)Egebjerg J; Garrett RA Binding sites of the antibiotics pactamycin and celesticetin on ribosomal RNAs. Biochimie. 1991, 73, 1145. [PubMed: 1720667] (b)Carter AP; Clemons WM; Brodersen DE; Morgan-Warren RJ; Wimberly BT; Ramakrishnan V Functional insights from the structure of the 30S ribosomal subunit and its interactions with antibiotics. Nature 2000, 407, 340. [PubMed: 11014183] (c)Dinos G; Wilson DN; Teraoka Y; Szaflarski W; Fucini P; Kalpaxis D; Nierhaus KH Dissecting the ribosomal inhibition mechanisms of edeine and pactamycin: the universally conserved residues G693 and C795 regulate P-site RNA binding. Mol. Cell 2004, 13, 113. [PubMed: 14731399] (d)Tourigny DS; Fernández IS; Kelley AC; Vakiti RR; Chattopadhyay AK; Dorich S; Hanessian S; Ramakrishnan V Crystal structure of a bioactive pactamycin analog bound to the 30S ribosomal subunit. J. Mol. Biol 2013, 425, 3907. [PubMed: 23702293]

(4). (a)Hanessian S; Vakiti RR; Dorich S; Banerjee S; Lecomte F; DelValle JR; Zhang J; DeschênesSimard B Total synthesis of pactamycin. Angew. Chem. Int. Ed 2011, 50, 3497.(b)Malinowski JT; Sharpe RJ; Johnson JS Enantioselective synthesis of pactamycin, a complex antitumor antibiotic. Science 2013, 340, 180and references therein. [PubMed: 23580525] 
(5). (a)Gerstner NC; Adams CS; Grigg RD; Tretbar M; Rigoli JW; Schomaker JM Diastereoselective Synthesis of the Aminocyclitol Core of Jogyamycin via an Allene Aziridination Strategy. Org. Lett 2016, 18, 284-287. [PubMed: 26741730] (b)Adams CS; Boralsky LA; Guzei IA; Schomaker JM Modular functionalization of allenes to aminated stereotriads. J. Am. Chem. Soc 2012, 134, 10807-10810. [PubMed: 22708990] (c)Adams CS; Grigg RD; Schomaker JM Complete stereodivergence in the synthesis of 2-amino-1, 3-diols from allenes. Chem. Sci 2014, 5, 30463056.

(6). Trost BM; Zhang L; Lam TM Synthesis of the Aminocyclitol Core of Jogyamycin via an Enantioselective Pd-Catalyzed Trimethylenemethane (TMM) Cycloaddition. Org. Lett 2018, 20, 3938-3942. [PubMed: 29939033]

(7). Ichikawa Y New synthetic method for allylic isocyanates through [3, 3] sigmatropic rearrangement of allylic cyanates. Synlett 1991, 4, 238-40.

(8). (a)Nocquet P-A; Henrion S; Macé A; Carboni B; Villalgordo JM; Carreaux F The Allyl Cyanate/ Isocyanate Rearrangement: An Efficient Tool for the Stereocontrolled Formation of Allylic C-N Bonds. Eur. J. Org. Chem 2017, 1295-1307.(b)Hama N; Matsuda T; Sato T; Chida N Total synthesis of (-)-agelastatin A: The application of a sequential sigmatropic rearrangement. Org. Lett 2009, 11, 2687-90 and references therein. [PubMed: 19449885]

(9). Germain N; Guénée L; Mauduit M; Alexakis A Asymmetric conjugate addition to a-substituted enones/enolate trapping. Org. Lett 2014, 16, 118-121. [PubMed: 24320076]

(10). For an mCPBA oxidation of a cyclopentyl silyl enol ether, see: Hashimoto S; Katoh S-I; Kato T; Urabe D; Inoue M Total Synthesis of Resiniferatoxin Enabled by Radical-Mediated ThreeComponent Coupling and 7-endo Cyclization. J. Am. Chem. Soc 2017, 139, 16420-16429. [PubMed: 29041773]

(11). For an DMDO oxidation of a cyclopentanone derived potassium enolate, see: Kurzawa T; Harms $\mathrm{K}$; Koert U Stereoselective Synthesis of the Benzodihydropentalene Core of the Fijiolides. Org. Lett 2018, 20, 1388-1391. [PubMed: 29450998]

(12). Nicolaou KC; Gray DLF; Montagnon T; Harrison ST Oxidation of Silyl Enol Ethers by Using IBX and IBX-N-Oxide Complexes: A Mild and Selective Reaction for the Synthesis of Enones. Angew. Chem. Int. Ed 2002, 41, 996-1000.

(13). Takeda N; Imamoto T Use of Cerium (III) Chloride in the Reactions of Carbonyl Compounds with Organolithiums or G rignard Reagents for the Suppression of Abnormal Reactions: 1-Butyl1, 2, 3, 4-Tetrahydro-1-Naphthol. Org. Synth 1999, 76, 228.

(14). Caddick S; Cheug S; Doyle VE; Frost LM; Soscia MG; Delisser VM; Williams MRV; Etheridge ZC; Khan S; Hitchcock PB; Pairaudeau G; Vile S Stereoselective synthesis of polyfunctionalised hydroxylated cyclopentanes from dihydroxylated 2-cyclopentenone derivatives. Tetrahedron 2001, 57, 6295-6303.

(15). Ścianowski J; Pacuła AJ; Zielińska-Błajet M; Wojtczak A Diphenyl diselenides o-substituted by an $\mathrm{O}(\mathrm{S}, \mathrm{Se})$-caranyl skeleton-synthesis and application in asymmetric reactions. New J. Chem 2016, 40, 6697-6705.

(16). (a)Christophersen C; Holm A Alkyl Cyanates. Acta. Chem. Scand 1970, 24, 1512-1526. (b)Overman LE; Kakimoto M-A Preparation of rearranged allylic isocyanates from the reaction of allylic alkoxides with cyanogen chloride. J. Org. Chem 1978, 43, 4564-4567.(c)Ichikawa Y Evolution, development and personal experience in studies of the allyl cyanate-to-isocyanate rearrangement. Synlett 2007, 2927-2936.

(17). (a)Guanti G; Banfi L; Narisano E; Zannetti MT Synthesis of both top and bottom fragments of (-)-talaromycin A through enantiospecific and diastereoselective elaboration of asymmetrized tris (hydroxymethyl) methane. J. Org. Chem 1993, 58, 1508-1514.(b)Takahashi K; Yamaguchi D; Ishihara J; Hatakeyama S Total Synthesis of (-)-Kaitocephalin Based on a Rh-Catalyzed C-H Amination. Org. Lett 2012, 14, 1644-1647. [PubMed: 22390213]

(18). Overman LE; Carpenter NE The Allylic Trihaloacetimidate Rearrangement. in Organic Reactions; 2005, doi:10.1002/0471264180.or066.01.

(19). Feldman AK; Colasson B; Sharpless KB; Fokin VV The allylic azide rearrangement: Achieving selectivity. J. Am. Chem. Soc 2005, 127, 13444-5 and references therein. [PubMed: 16190677]

(20). Armarego WLF; Chai CLL Purification of Laboratory Chemicals 6th ed, Elsevier: Burlington, MA, 2009. 
(21). Still WC; Kahn M; Mitra A Rapid chromatographic technique for preparative separations with moderate resolution J. Org. Chem 1978, 43, 2923. 


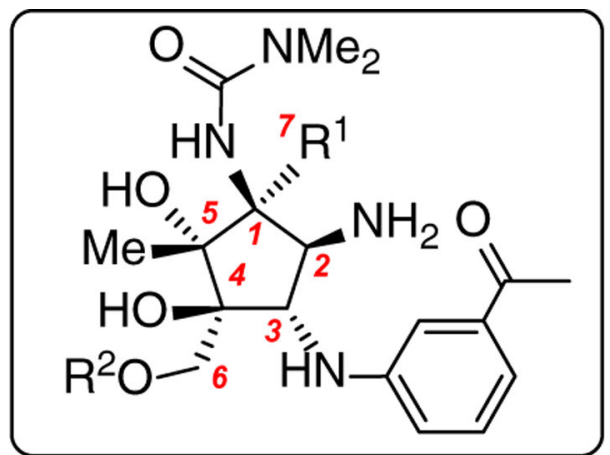

$\mathbf{R}^{1} \quad \mathbf{R}^{\mathbf{2}}$

$\mathrm{MSA}=$ 6-methyl salicylate<smiles>COC(=O)c1c(C)cccc1O</smiles>
anti-

antibacterial malarial T.b.b. cytotoxicity

Et $\quad \mathrm{H}$ Jogyamycin

Staphylococcus P. f. K1 $1^{a}$ GUTat $3.1^{b}$ MRC-5

" 3/." $^{7}$ "OH MSA Pactamycin

$\begin{array}{llllll}\text { Et } & \text { MSA 7-Deoxypactamycin } 3 & 50 \mu \mathrm{M} & 0.4 \mathrm{nM} & 0.9 \mathrm{nM} & 74 \mathrm{nM}\end{array}$

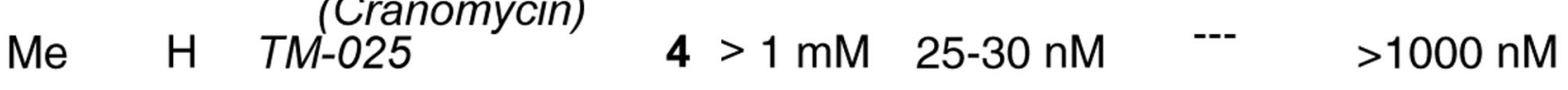

Me MSA TM-026 $\quad 5>1 \mathrm{mM}$

${ }^{a}$ Plasmodium falciparum $\mathrm{K} 1$ (resistant). ${ }^{b}$ Trypanosoma brucei brucei.

Figure 1.

Bioactive aminocyclopentitol natural products. 

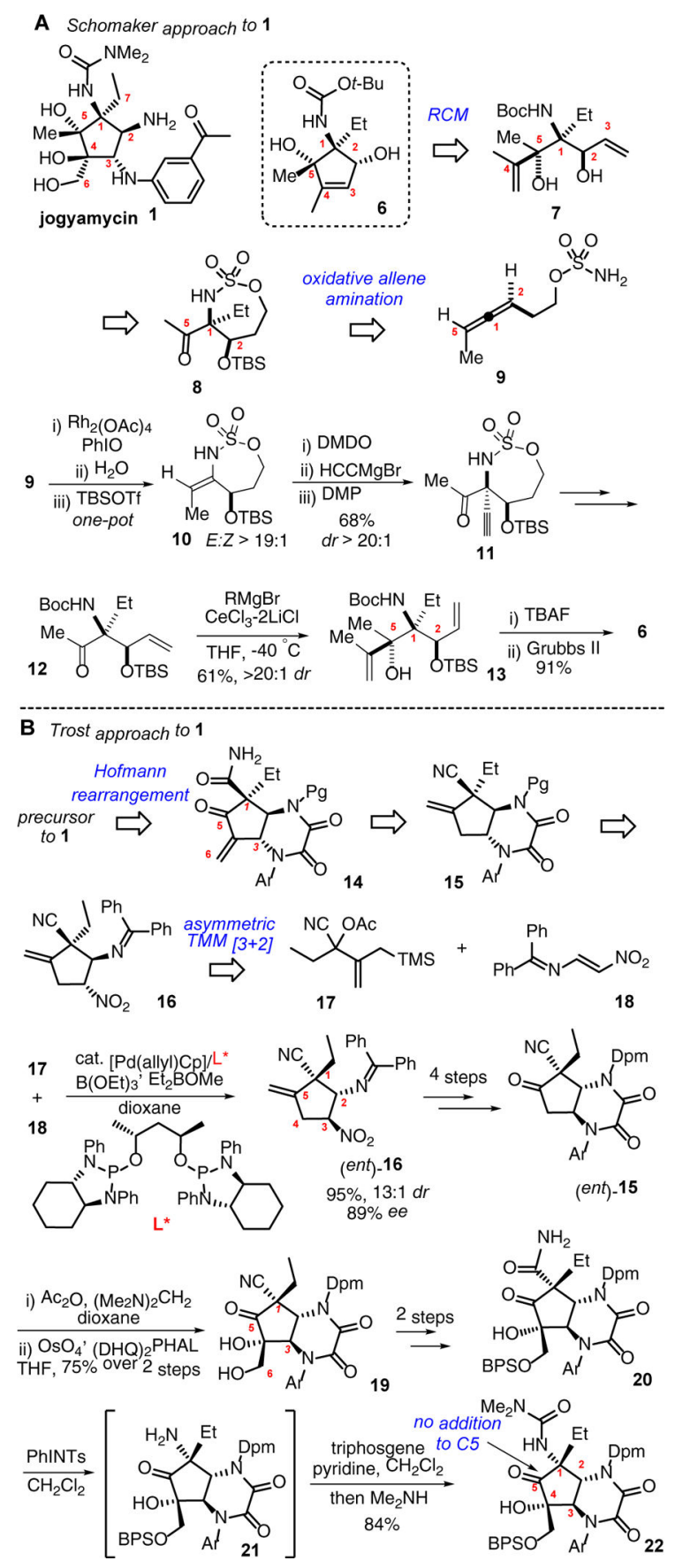

Scheme 1.

Two previous approaches to jogyamycin $\mathbf{1}$. 
<smiles>C[In][C@@]1(NC(N)=O)[C@H](N)[C@@H](Nc2cccc(C(C)=O)c2)[C@](O)(CO)[C@@]1(C)O</smiles><smiles>CC[C@]1(NC(=O)N(C)C)C=C[C@](C)(OC(=N)C(Cl)(Cl)Cl)[C@@]1(C)OC</smiles><smiles>CC[C@]1(NC(N)=O)[C@H](NC(=O)C(Cl)(Cl)Cl)C=C(C)[C@]1(C)OC(=O)O</smiles>

Overman rearrangement
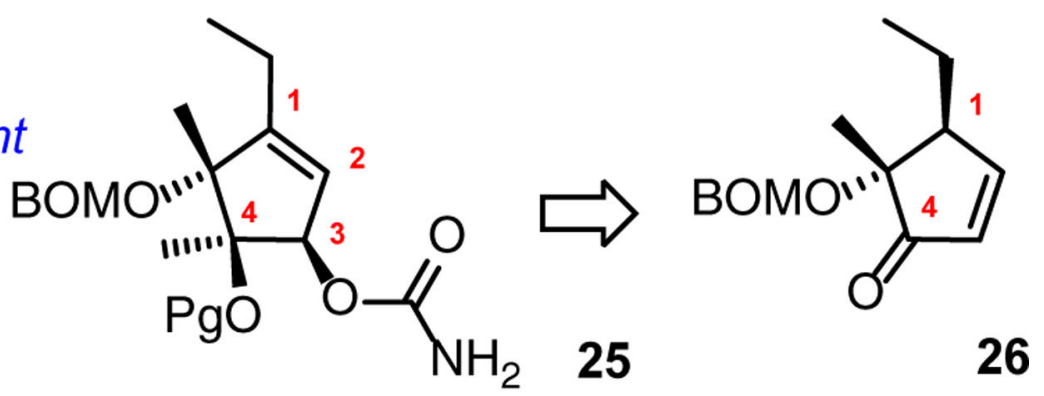

Scheme 2.

Retrosynthesis of $\mathbf{1}$ via an Ichikawa/Overman rearrangement strategy. 

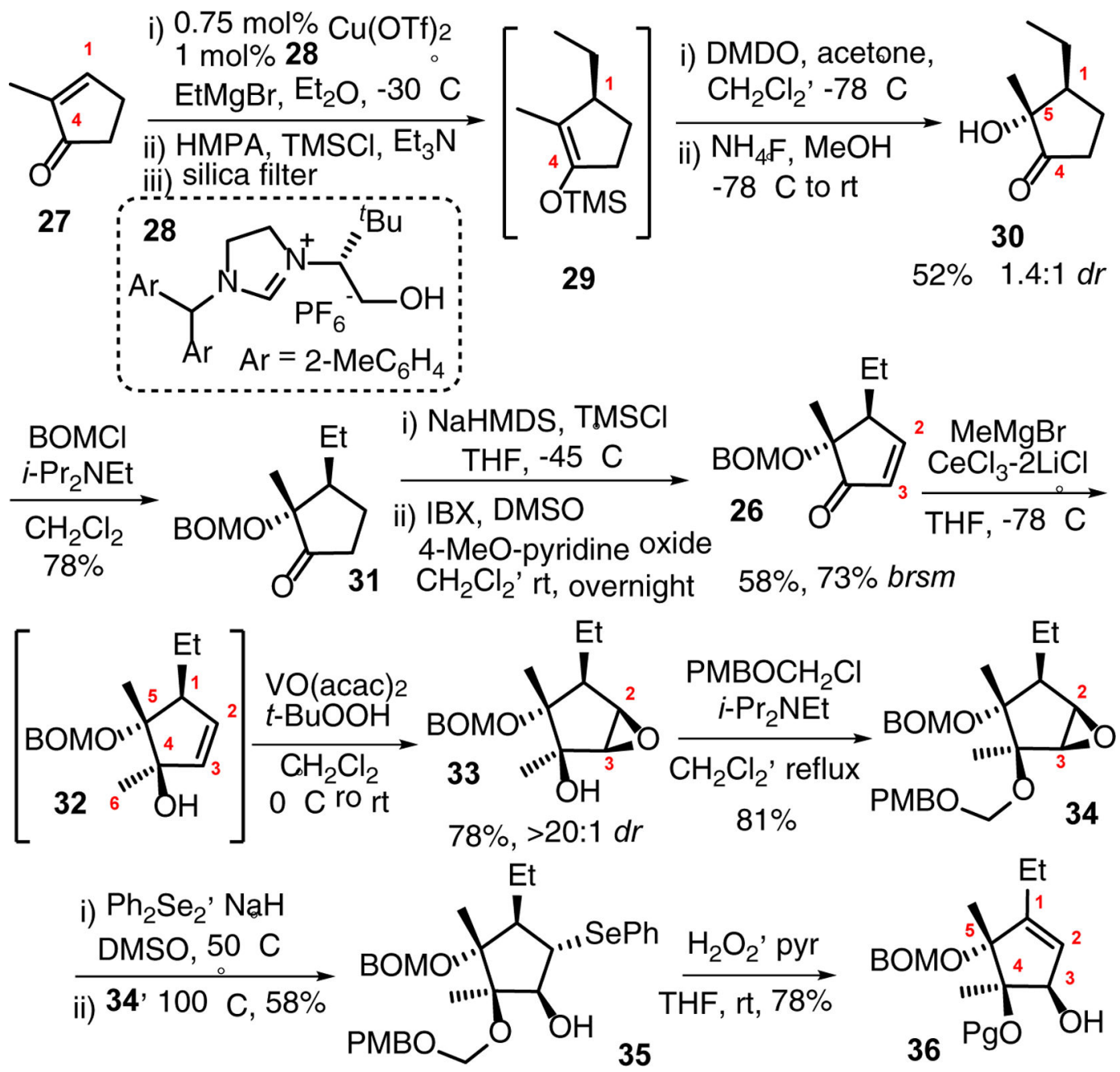

Scheme 3.

Preparation of Ichikawa rearrangement precursor. 


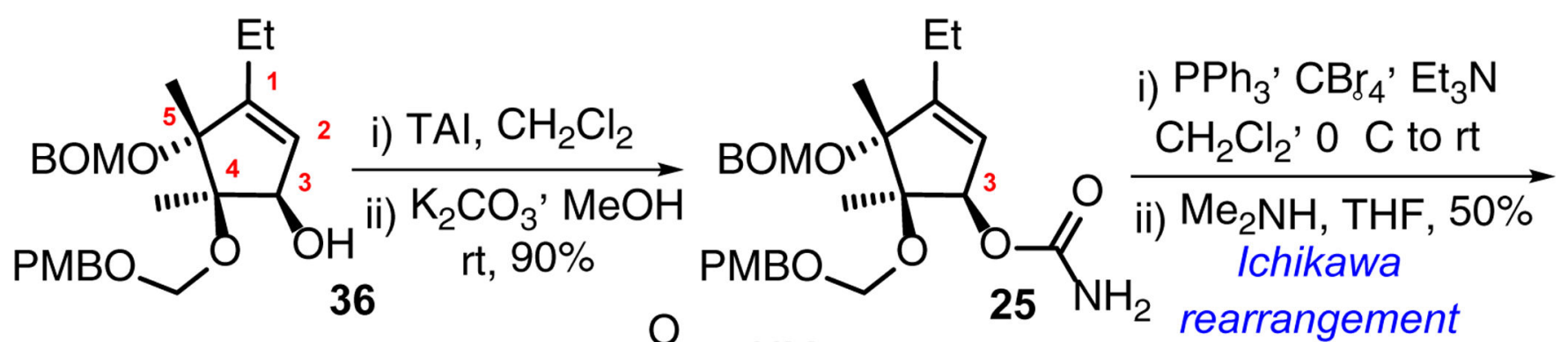

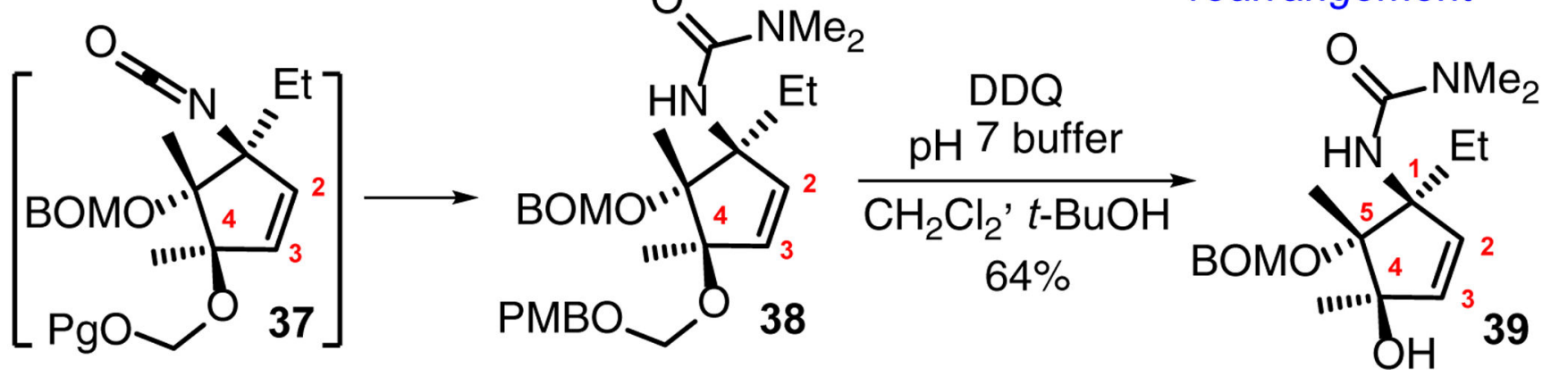

Scheme 4.

Successful Ichikawa rearrangement. 


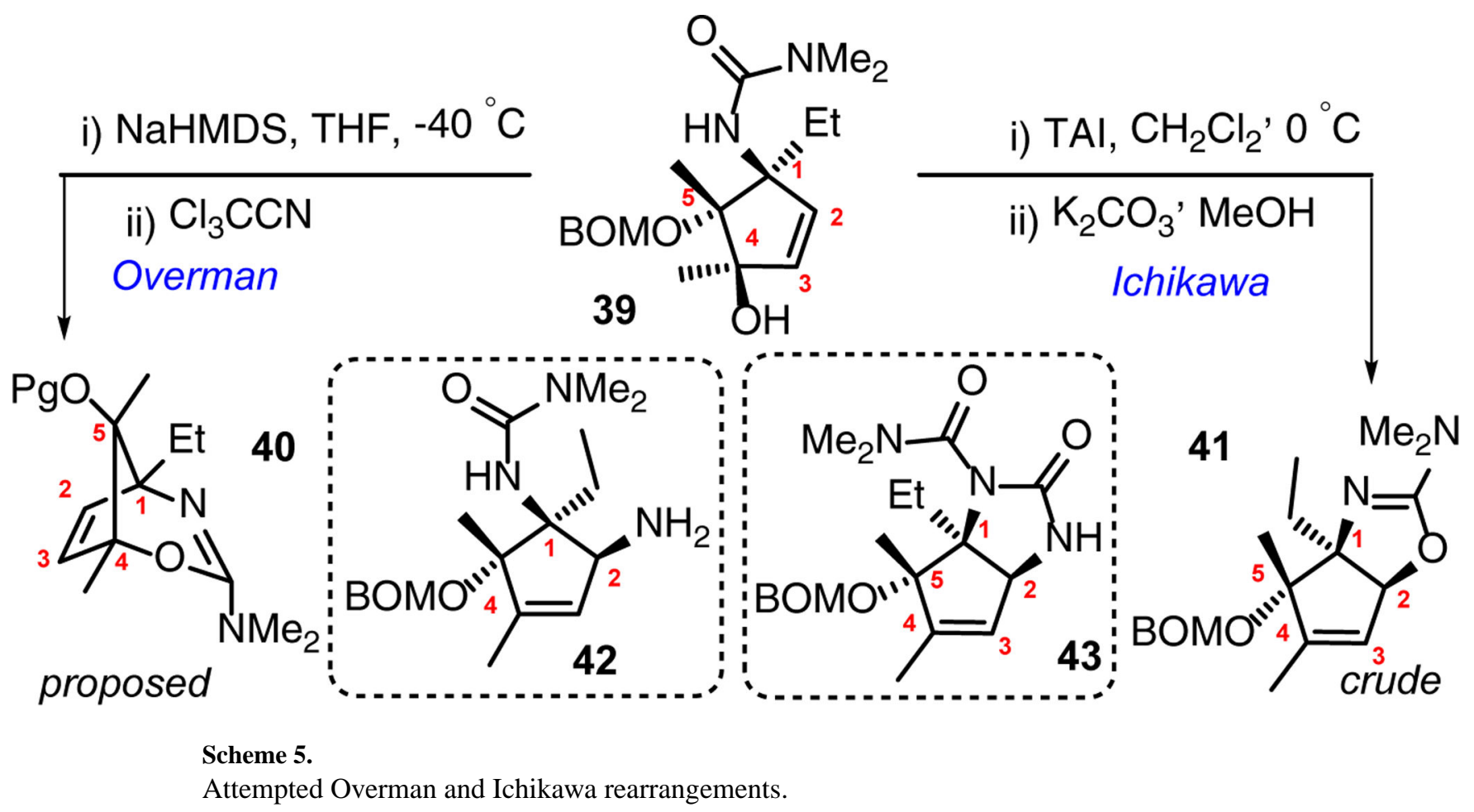

